Original article

\title{
Biochemical characterization of somatic embryogenesis and genetic transformation studies in Terminalia chebula Retz.: An immensely valuable medicinal tree
}

\author{
C. Anjaneyulu and Charu Chandra Giri \\ Centre for Plant Molecular Biology (CPMB), Osmania University, Hyderabad-500007, Telangana, India
}

Received April 3, 2018: Revised May 17, 2018: Accepted May 20, 2018: Published online June 30,2018

\begin{abstract}
The present communication reports a study involving Terminalia chebula Retz., with the elucidation of biochemical changes that occur during somatic embryogenesis and genetic transformation promise in this important slow growing valuable medicinal tree. T. chebula is an economically important plant, used in ayurvedic, unani medicine, and raw material for tanning industry. Callus induction, growth and somatic embryogenesis induction process was exploited for biochemical and genetic transformation studies in T. chebula. Biochemical analysis of proteins associated with somatic embryogenesis was studied and compared with mature zygotic embryo specific proteins using SDS-PAGE. SDS-PAGE protein profile analysis revealed precise association of proteins such as $21,24,30,42,52$, and $85 \mathrm{kDs}$ with induction of somatic embryogenesis compared to their absence in non-embryogenic callus. Some proteins such as 16, 22, 25, 29, 31, $55,68,80,125 \mathrm{kDs}$ were common both in non-embryogenic callus and embryogenic callus across different developmental stages. A comparative study of embryo specific proteins in somatic embryos and zygotic embryos also revealed that the proteins such as $21,24,30,42,52,85 \mathrm{kDs}$ were specific to somatic embryos, but absent in zygotic embryos. Further, additional numbers of protein bands such as 16, 22, 36, 40, 55, 68, $70 \mathrm{kDs}$ expressed both in non-embryogenic and embryogenic callus, respectively; when compared to zygotic embryos. Genetic transformation was carried out using Agrobacterium tumefaciens strain LBA 4404 containing super binary vector pTOK 233. Amongst the explants evaluated, acetosyringone pretreated embryogenic callus dipped in PIM II bacterial suspension was found to be suitable for co-cultivation with $A$. tumefaciens and genetic transformation. The highest transformation frequency $(5.20 \pm 1.45$ hygromycin resistant calli, $4.44 \pm 1.76$ GUS expression) was obtained with $100 \mu \mathrm{M}$ acetosyringone pretreated embryogenic calli. Present study presents a detailed biochemical assessment of somatic embryogenesis and positives on genetic transformation in T. chebula using embryogenic callus culture system.
\end{abstract}

Key words: Terminalia chebula Retz., biochemical study, somatic embryogenesis, embryo specific proteins, genetic transformation, hygromycin resistance, GUS expression

\section{Introduction}

Terminalia chebula Retz. $(2 \mathrm{n}=48)$ is a medicinal tree belongs to the family Combretaceae (Ohri 1996). This tree is distributed in the sub-Himalayan tracts, West Bengal, Assam, Madhya Pradesh, Maharashtra, Odisha, Tamil Nadu, present day Andhra Pradesh and Telangana State, India involving an array of geological formations. In Indian pharmacopoeia, fruit of $T$. chebula is extensively used as an adjuvant to many medicines for almost all diseases with special reference to Ayurvedic, Unani and Iranian medicaments (Khare, 2004; Jokar et al., 2016). Specifically, the pericarp of dried ripe fruits is used in the preparation of many Ayurvedic formulations for infectious diseases such as jaundice, splenopathy, hiccough, cephalagia, epilepsycough, asthma, urinary

Author for correspondence: Dr. Charu Chandra Giri Professor, Centre for Plant Molecular Biology (CPMB), Osmania University, Hyderabad-500007, Telangana State, India

E-mail: giriccin@yahoo.co.in

Tel.: +91-040-27098087

Copyright @ 2018 Ukaaz Publications. All rights reserved.

Email: ukaaz@yahoo.com; Website: www.ukaazpublications.com diseases, piles, worms, obesity, eye infections, peptic ulcers, chronic constipation, and leprosy (Chadha 1989; Warrier et al., 1997). T. chebula is one of the constituents used in Ayurvedic medicine "Triphala". Naarikelaanjana (Aarogya Kalpadruma, IMPCOPS) an herbal eye drop containing Triphala is used for acute and chronic conjunctivitis (Khare, 2004). T. chebula seeds contain chebulin which have antispasmodic activity similar to that of papavarine. $T$. chebula extracts were found to show inhibitory activity against HIV-I protease, influences dermal wound healing and also shown antibacterial activity (Xu et al., 1996; Sandip 2003; Suguna et al., 2002; Bonjar 2004; Saxena et al., 2017). T. chebula also have antioxidant activity, inhibitory effect on malignant cell lines such as human prostate cancer cell line and erythroid differentiation (Jaya et al., 2004; Yi et al., 2004; Saha and Verma 2017). Immature seeds of $T$. chebula are used in the development of therapies for managing rheumatoid arthritis and other inflammatory diseases and have shown cardioprotective effect (Lee et al., 2005; Suchalatha and Shyamala, 2004). The influence of T. chebula on Alzheimer's disease, larvicidal, ovicidal, antidiabetic activity and protective effect against seizures has also been reported (Afshari et al., 2016; Veni et al., 2017; Lee et al., 2017; Kumar et al., 2018). Further, recently it 
has been found that hydrolysable tannins and related compounds from $T$. chebula could be used as potential treatment for dementia (Kim et al., 2018).

Somatic embryogenesis is one of the potential pathways of regeneration for large scale micropropagation of woody and economically important plants (Guan et al., 2016; Georgeta et al., 2017). Further, somatic embryogenesis is an ideal experimental system for understanding totipotency, cell differentiation, and plant development. However, till date existing knowledge on genetic, biochemical and molecular basis of somatic embryogenesis is meager and fragmented. Not enough progress has been made in the past towards understanding the embryogenesis at biochemical level too with particular reference to trees. Further, very few reports on these aspects are available. The study of somatic embryogenesis specific proteins by SDS-PAGE and 2-dimentional gel electrophoresis has given new dimensions about our understanding of the process of somatic embryogenesis (Imin et al., 2005). Further, cork oak somatic embryos have also been studied for developmentally regulated stress-induced small heat shock proteins (Puigderrajols et al., 2002). Besides proteins, developmental changes of catalase, superoxide dismutase isoenzymes in zygotic and somatic embryos of horse chesnut was also investigated (Bagnoli et al., 2005). Biochemical characterization of somatic embryogenesis in Cardiospermum halicacabum has also been reported (Jeyaseelan and Rao 2005). SDS-PAGE protein profile analysis has also been used to study the embryo specific proteins (Rojarani et al., 2005). Most recently, wide-ranging proteomics analysis in Picea asperata somatic embryos has also been reported revealing the importance of this area of study (Jing et al., 2017). Keeping in view the importance of proteomics approach of understanding the mechanism of somatic embryogenesis process, it becomes important to analyze the gene product as protein. SDS-PAGE profiling of proteins related to the somatic embryogenesis process becomes relevant in the present context.

Keeping in view the inherent bottlenecks associated with the conventional tree breeding/genetic improvement programme, the advances on in vitro culture and genetic transformation strategies in tree species, biotechnological interventions can bring about amicable solutions as a supplement (Giri et al., 2004; Josefina and Patricio 2005; Häggman et al., 2013; Häggman et al., 2016; Andrade et al., 2017). Our lab is associated with the area of research on biotechnological interventions in $T$. chebula for rapid multiplication of this important medicinal tree for forestry (Shyamkumar et al., 2003; Anjaneyulu et al., 2008; Shyamkumar and Giri 2011; Anjaneyulu and Giri 2011). There has been a constant need to develop protocols for genetic transformation in tree species in general and $T$. chebula in particular for genetic improvement (Giri et al., 2004; Shyamkumar et al., 2007; Dangi et al., 2012; Verma et al., 2013; Zuo et al., 2018). In the present communication, we report biochemical analysis and genetic transformation studies using somatic embryogenesis culture system of T. chebula

\section{Materials and Methods}

\subsection{Plant material}

The plant material of the present study Terminalia chebula Retz., is a tree belongs to the family Combretaceae. The plant materials (mature and immature seeds) were collected during the month of January to October of each year from $T$. chebula trees growing in its natural forest habitat of Mayurbhanj district in the eastern part of Odisha, Tiger Forest Reserve, Srisailam, and Ananthagiri Hills forest area, Vikarabad, Telangana State, India. Plant materials were collected and brought to laboratory conditions in Centre for Plant Molecular Biology (CPMB), OU, Hyderabad, India and processed by shade, sun drying and used for their evaluation in different experiments.

\subsection{Surface sterilization of excised mature zygotic embryos (MZE) and establishment of aseptic cultures}

To avoid contamination of bacteria, fungi, the MZE explants were surface sterilized before they were used for establishment of in vitro axenic cultures. The pericarp of the mature yellowish green seeds was removed using sharp scalpel blade. Alternately hard pericarp of the dried seeds was removed by breaking with a heavy stone or iron device. The seeds with hard testa were kept in distilled water for 1-2 days in the refrigerator for softening. The mature embryos were excised from seed testa mechanically using an indigenously designed bench vice. The surface sterilization of excised mature zygotic embryos was carried out using steps as follows:

Step I: The undamaged intact excised MZE explants were surface sterilized with $0.1 \%(\mathrm{w} / \mathrm{v})$ fungicide bavistin solution for $20 \mathrm{~min}$, and thoroughly rinsed with sterile distilled water for 5-6 times.

Step II: The excised MZE were further disinfected with $0.1 \%$ (w/ v) mercuric chloride for 5-6 min. The mercuric chloride solution was then decanted off and the MZE explants were rinsed thoroughly with sterile distilled water for 6-8 times giving each $5 \mathrm{~min}$ wash to remove the remaining traces of mercuric chloride.

\subsubsection{Evaluation of media combinations on callus induction in $T$. chebula}

Basal media such as MS: Murashige and Skoog (1962), WPM: Lloyd and McCown (1980), DKW: (Driver and Kuniyuki 1984; Mc Granahan et al., (1987) were used in the present study. Sucrose at $3 \%(\mathrm{w} / \mathrm{v})$ used for all three types of basal media with $\mathrm{pH}$ : for MS $5.8 \pm 0.1$, WPM: $5.6 \pm 0.1$, DKW: $5.5 \pm 0.1$. Plant growth regulators (PGRs) such as 2, 4-dichlorophenoxyacetic acid (2, 4-D), indolebutryic acid (IBA), naphthalene acetic acid (NAA), kinetin $(\mathrm{KN})$, benzyladenine (BA), and abscisic acid (ABA) were used. Different concentrations and combinations of the plant growth regulators were supplemented to MS, WPM and DKW basal media. MZE explants were used for callus induction. Excised mature zygotic embryos of size 15-17 $\mathrm{mm}$ were cultured on media containing MS salts and vitamins with $30 \mathrm{~g} / \mathrm{l}$ sucrose. Various concentrations of 2, 4-D $(0.0,0.2,0.5,1.0,2.0,3.0,4.0$ and $5.0 \mathrm{mg} /$ 1) either alone or in combination with $\mathrm{KN}(0.0,0.01,0.1,0.25$ and $0.5 \mathrm{mg} / \mathrm{l})$ or BA $(0.0,0.01,0.1,0.25$ and $0.5 \mathrm{mg} / \mathrm{l})$ were evaluated for callus initiation. In addition, IBA $(0.0,0.2,0.5,1.0,2.0,3.0,4.0$ and $5.0 \mathrm{mg} / \mathrm{l})$, NAA $(0.0,0.2,0.5,1.0,2.0,3.0,4.0$ and $5.0 \mathrm{mg} / \mathrm{l})$ was also evaluated with same concentration of $\mathrm{KN}$ and $\mathrm{BA}$ for induction of callus.

\subsubsection{Inoculation of explants, culture conditions and Induction of somatic embryos in T.chebula}

MZE induced callus pieces weighing approximately 250-300 mg were inoculated onto the media in each treatment in replicates studied and considered as a single explant for induction of somatic embryogenesis. Detailed day-to-day observations on the growth and texture of callus was recorded. Master cultures were maintained 
by repeatedly sub-culturing the healthy, fast growing pieces on fresh medium for every 4 weeks.

MZE, calluses, somatic embryos, and germinated seedlings were inoculated on Murashige and Skoog 1962 (MS) basal medium at 25 $\pm 2^{\circ} \mathrm{C}, 80 \%$ relative humidity in dark or light conditions under $16 \mathrm{hr}$ photoperiod with a light intensity of 3000 lux provided by cool white fluorescent tubes. Somatic embryo induction was evaluated with MS medium containing different concentrations of sucrose (30,40, 50, $60 \mathrm{~g} / \mathrm{l})$ using in vitro cultures of $T$. chebula derived from MZE explants. A minimum 24 replicates for initiation of somatic embryogenesis were used in each experiment. 2.3 Biochemical characterization of somatic embryogenesis
by SDS PAGE

\subsubsection{Extraction of proteins from plant tissue}

Approximately $0.5 \mathrm{~g}$ of non-embryogenic callus, embryogenic callus at different developmental stages of somatic embryos (1 week, 2 weeks, cotyledonary somatic embryos) and mature zygotic embryos was taken separately in a pre-chilled mortar with small amount of protein extraction buffer (Tris Hcl-0.20 M, Mercaptoethanol-0.03\%, Coomassie Brilliant Blue, Dithiothreitol$10.00 \mathrm{mM}$ and $\mathrm{MgCl}_{2} \cdot 6 \mathrm{H}_{2} \mathrm{O}-2.0 \mathrm{mM}$ ). Tissues were ground in pre-chilled mortar and pestle until complete disruption of cells was evident. Alternately, pre-chilled fine sand particles were also used along with extraction buffer for efficient breaking of plant tissue. Protein extraction buffer was then added along the sides of the mortar and mixed well. Total tissue macerate in extraction buffer was filtered through a mousseline cloth and transferred to eppendorf tubes and repeated the process as on when necessary. Approximately $1.0 \mathrm{ml}$ of filtrate was taken in an eppendorf tubes and centrifuged at $15000 \mathrm{rpm}$ for $35 \mathrm{~min}$ at $4^{\circ} \mathrm{C}$ (Sigma $3 \mathrm{~K} 30$ Laboratory centrifuge, Germany). The supernatant was collected and stored at $-70^{\circ} \mathrm{C}$ and this supernatant served as protein sample for SDS-PAGE. The extracted protein was quantified by Bradford method (1976) and SDS-PAGE of the samples were carried out following electrophoresis protocols as described by Laemmli (1970). SDS-PAGE was done using vertical gel electrophoresis unit (Gene1 Mini, Bangalore, India) on 15\% separating gel and 5\% stacking gels. The SDS-poly acrylamide gel was scanned using hp Scan jet 2400 for obtaining high resolution photographs.

\subsubsection{Genetic transformation using Agrobacterium tumefaciens strain LBA4404 containing pTOK233}

Co-cultivation experiments were carried out using Agrobacterium tumefaciens strain LBA4404 containing super binary vector pTOK233 for the genetic transformation of T.chebula (Ramesh et al., 2004). This vector was with reporter gene gusA, along with selectable marker gene hygromycin phosphotransferase (Figure 1).

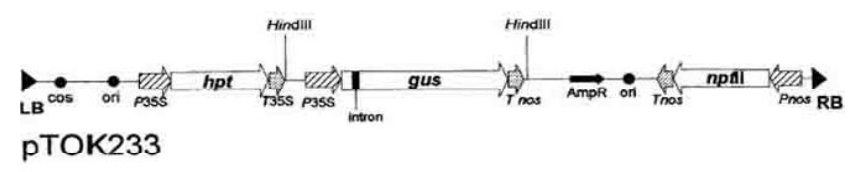

Figure 1: Agrobacterium tumefaciens strain LBA 4404 containing vector pTOK233 with T-DNA region. Hpt-hygromycin phosphotransferase; gus- $\beta$-glucuronidase; LB-left border; RB-right border.

\subsubsection{Growth of Agrobacterium tumefaciens strain LBA4404 containing super binary vector pTOK233}

\subsubsection{Culture of bacteria}

Initially, bacterial culture was initiated by streaking of bacterial culture from the glycerol stock on to YEP (Peptone $10.0 \mathrm{~g} / \mathrm{l}$, Yeast extract $10.0 \mathrm{~g} / \mathrm{l}$, Sodium chloride $5.0 \mathrm{~g} / \mathrm{l}$, Final $\mathrm{pH}$ (at $25^{\circ} \mathrm{C}$ ) $7.0 \pm$ 0.2 ) solid medium using a sterile inoculation loop. A single colony was picked from the agar plate with a sterile toothpick and inoculated into two vials containing $5 \mathrm{ml}$ each of YEP liquid medium with 50 $\mathrm{mg} / \mathrm{l} \mathrm{hygromycin}$. The vials were kept on shaker at $29^{\circ} \mathrm{C}$ with 225 $\mathrm{rpm}$ in the dark for $24 \mathrm{~h}$. The above bacterial culture was centrifuged at $3000 \mathrm{rpm}$ for $15 \mathrm{~min}$. The pellet cells were re-suspended in $10 \mathrm{ml}$ of PIM II medium (Glucose 1\% + MES $75 \mathrm{mM}+\mathrm{NaPO}_{4}$ buffer $2 \mathrm{mM}$ pH $5.6+1 \mathrm{X} \mathrm{AB}$ salts $\left(\mathrm{NH}_{4} \mathrm{Cl}, \mathrm{MgSO}_{4} 7 \mathrm{H}_{2} \mathrm{O}, \mathrm{KCl}, \mathrm{CaCl}_{2}\right.$ and $\mathrm{FeSO}_{4} \cdot 7 \mathrm{H}_{2} \mathrm{O}$ ) containing $100 \mu \mathrm{M}$ acetosyringone in sterile conical flask. The conical flask was kept in an incubator shaker at $225 \mathrm{rpm}$ and $29^{\circ} \mathrm{C}$ temperature for $16 \mathrm{~h}$. The cultures reached an O.D of 1.0 to $1.5\left(\mathrm{~A}_{600}\right)$ after $16 \mathrm{~h}$ of culture. Exponential bacterial growth with an optical density ranging from $1.0-1.5$ was used for the cocultivation experiments.

\subsubsection{Evaluation of cefotaxime concentrations on the control of bacterial growth}

After a co-cultivation period of one to four days, the explants along with bacterial growth were transferred on to fresh callus induction medium CIM (MS + 2,4-Dmg/l + KN0.01 mg/l + $30 \mathrm{~g} / \mathrm{l}$ sucrose, agar $9 \mathrm{~g} / \mathrm{l}, \mathrm{pH}$ 5.8) containing 0, 100, 200, 250, 300, 350 and $400 \mathrm{mg} / \mathrm{l}$ cefotaxime. All the cultures were maintained in darkness at $25 \pm 2{ }^{\circ} \mathrm{C}$.

\subsubsection{Evaluation of lethal hygromycin concentration for non transformed embryogenic control callus}

The lethal concentration of selection agent hygromycin on embryogenic callus was evaluated. Embryogenic callus was placed on CIM containing different concentrations of hygromycin ranging from $5,10,20,40,60,80 \mathrm{mg} / \mathrm{l}$. Based on the results obtained from the experiments, the concentration of hygromycin which showed $100 \%$ lethality was used as selection medium for the selection of transformed calli in subsequent genetic transformation experiments.

\subsubsection{Methods of co-cultivation using LBA4404-pTOK233}

In the present work, freshly excised MZE cultured in callus induction medium for 5-6 days and 18-20 days, and embryogenic calli were maintained on MS medium supplemented with 2, 4-D $1.0 \mathrm{mg} / \mathrm{l}$ and $\mathrm{KN} 0.01$ is referred as callus induction medium (CIM). Co-cultivation medium CCM is same as CIM except the $\mathrm{pH}$ of the medium was 5.2 instead of 5.8. MZE explants cultured in callus induction medium for 5-6 days, 18-20 days and embryogenic calluses after 2 weeks of subculture in CIM were used for transformation experiments. Two types of co-cultivation protocols were followed for infecting explants with bacterial strain. The methods for cocultivation are given as follows.

\subsubsection{Pretreatment of explants before co-cultivation}

In order to see the effects of acetosyringone on tranformation, the explants were transferred to petridish containing $20 \mathrm{ml}$ of Cocultivation medium (CCM: CIM except $\mathrm{pH}$ 5.2) with filtered sterilized 50,100, $200 \mu \mathrm{M}$ acetosyringone and were incubated for 
$20 \mathrm{~min}$. The explants without acetosyringone pretreatment were used for co-cultivation experiments as control simultaneously.

Method I: Dipping of different explants in PIM II (Glucose 1\% w/ $\mathrm{v}+$ MES $75 \mathrm{mM}+\mathrm{NaPO}_{4}$ buffer $2 \mathrm{mM}$, pH $5.6+1 \mathrm{X} \mathrm{AB}$ salts consisting of $\mathrm{NH}_{4} \mathrm{Cl}, \mathrm{MgSO}_{4} 7 \mathrm{H}_{2} \mathrm{O}, \mathrm{KCl}, \mathrm{CaCl}_{2}$ and $\mathrm{FeSO}_{4} \cdot 7 \mathrm{H}_{2} \mathrm{O}$ ) bacterial suspension for $5 \mathrm{~min}, 10 \mathrm{~min}, 15 \mathrm{~min}$ time duration. The acetosyringone pretreated explants were then transferred to PIM II bacterial suspension and incubated for $10 \mathrm{~min}$. In all the experiments after blotting of explants on sterile tissue paper were inoculated on to CCM.

Method II: Pouring of PIM II bacterial suspension over different explants placed on CCM. The explants without bacterial suspension inoculated on to CCM were treated as control. In another experiment, in each plate 40 to 45 acetosyringone pretreated explants were placed on CCM and PIM II bacterial suspension was poured on each explant. All explants after co-cultivation were transferred to $\mathrm{CCM}$ and maintained in the dark at $25 \pm 2{ }^{\circ} \mathrm{C}$ for one, two, three and four days.

\subsubsection{Selection of hygromycin resistant callus}

Co-cultivated explants after 2 weeks were transferred from antibiotic medium with $350 \mathrm{mg} / \mathrm{l}$ cefotaxime to selection medium containing $350 \mathrm{mg} / \mathrm{l}$ cefotaxime and $60 \mathrm{mg} / \mathrm{l} \mathrm{hygromycin}$ [(hygromycin selection medium (CIM + hygromycin $60 \mathrm{mg} / \mathrm{l})$ ] for the selection of transformed tissues. Medium without hygromycin was kept for the growth of cultures obtained after co-cultivation as control. Hygromycin resistant calli were scored after four weeks of culture. The frequency of transformation was calculated as the percentage of hygromycin resistant calli.

\subsubsection{Transient assay for GUS expression and evaluation of transformation frequency}

After the genetic transformation, the transformed cultures were analyzed for transient GUS gene expression. GUS expression was studied 14 days after co-cultivation. A minimum of callus explants ranging from 45-49 were used for co-cultivation experiments and transient GUS assay. Histochemical GUS assay was carried out according to Jefferson (1987). The calli were incubated for two days at $37{ }^{\circ} \mathrm{C}$ in GUS staining solution and the number of calli showing GUS expression was recorded. After the co-cultivation and subsequent culture, the transformation frequency was evaluated by scoring the hygromycin resistant transformed calli and tissues showing positive for GUS gene expression. GUS gene expression was examined by carrying out GUS staining of only hygromycin resistant calli.

\section{Results and Discussion}

3.1 Effect of different concentrations and combinations of 2 , 4-D and $\mathrm{KN}$ on callus induction using excised mature zygotic embryo explants in T. chebula

Subsequent to the collection of seed material of T. chebula, the first explants to be obtained was mature zygotic embryo excised from hard coated seeds (Figure 2a). Mature zygotic embryo explants were initially evaluated for callus induction using different concentrations and combinations of 2, 4-D and kinetin in MS medium. Swelling was observed with protruding compact micro-calli on the surface of the mature zygotic embryo explants after 32 days of culture. Induction of callus was obtained in a range of concentrations and combinations of 2, 4-D 0.2-5.0 mg/l and 0.01-0.5 mg/l of KN (Table 1). Globular structures in the micro-callus were observed on the explants in callus induction medium in second subculture within 40-42 days from culture initiation in about eight specific 2, 4-D and $\mathrm{KN}$ combinations. The overall percentage of cultures showing callus induction ranged from minimum of $37.77 \pm 2.02$ to a maximum of $94.44 \pm 0.66$ using mature zygotic embryo explants (Table 1 ). Embryogenic callus induction was obtained when 2, 4-D (0.5, 1, 2 $\mathrm{mg} / \mathrm{l})$ and $\mathrm{KN}(0.01,0.1,0.25 \mathrm{mg} / \mathrm{l})$ was used (Figure 2c). Maximum percentage of embryogenic callus induction $(91.66 \pm 2.08)$ was obtained with 2, 4-D $2 \mathrm{mg} / \mathrm{l}$ and kinetin $0.1 \mathrm{mg} / \mathrm{l}$ within 6 weeks of culture. A low percentage of embryogenic callus induction (56.11 \pm 2.33) was obtained on media supplemented with 2, 4-D $0.5 \mathrm{mg} / \mathrm{l}$ and $\mathrm{KN} 0.01 \mathrm{mg} / \mathrm{l}$. However, other 2, 4-D and kinetin combinations did not promote induction of embryogenic callus within 6 weeks of culture. There was a remarkable reduction in frequency of callus induction when 2, 4-D was used alone irrespective of its concentration (Table 1).

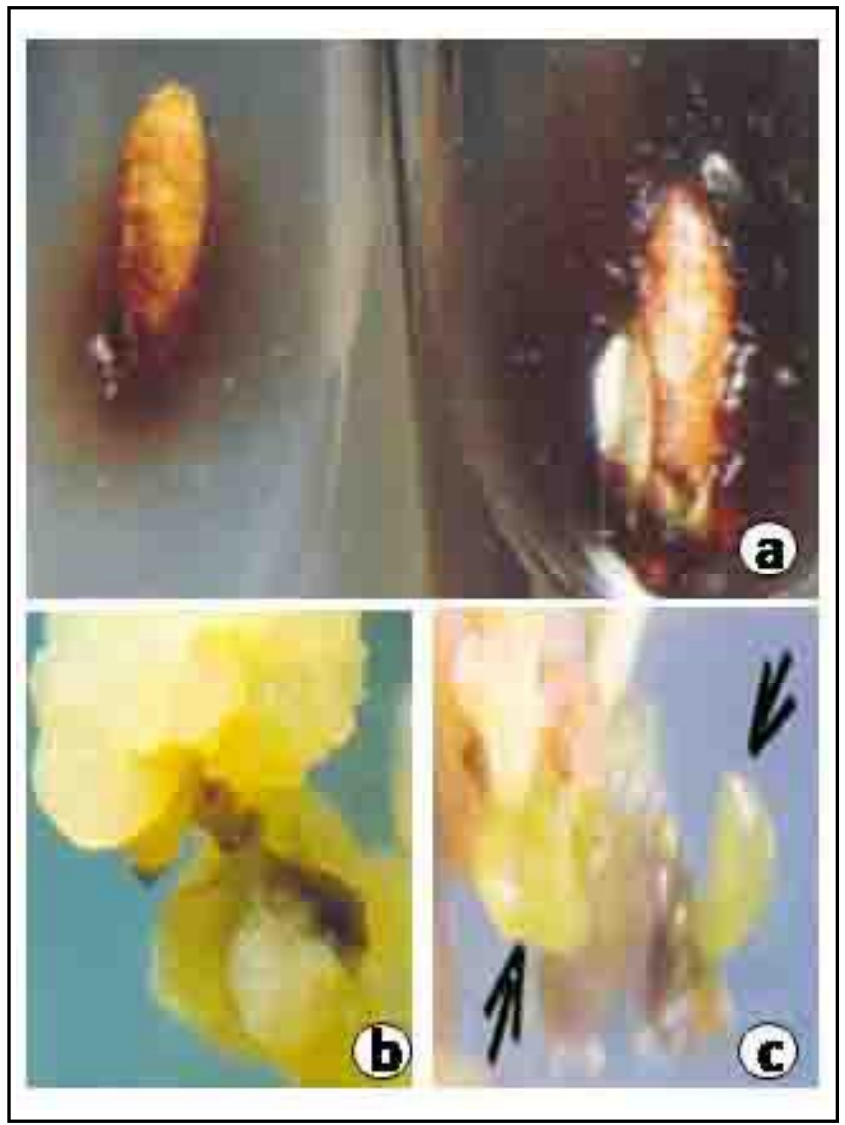

Figure 2: Induction of somatic embryogenesis in T. chebula a. Callus induction of from intact MZE explants; (left freshly inoculated; right swelling of MZE on culture); b. Further growth and proliferation of MEZ derived callus; c. Induction of somatic embryos (arrow) from MZE derived callus.

\subsubsection{Evaluation of different basal media for callus induction using excised MZE in T. chebula}

Evaluation of different basal media for callus induction was studied after obtaining optimum 2, 4-D and KN combinations from preliminary experiments (Table 1). MS basal medium showed best 
response in terms of percentage of callus induction $(90.55 \pm 2.33)$. Different media such as MS, WPM, and DKW was evaluated for callus induction and somatic embryogenesis (Table 2). During evaluation of basal media it was found that only MS basal media was able to induce embryogenic callus compared to DKW and WPM.

Table 1: Effect of different concentrations and combinations of 2 , 4-D and KN on callus induction from mature zygotic embryo explants in T. chebula*

\begin{tabular}{|c|c|c|}
\hline 2, 4-D (mg/l) & KN (mg/l) & $\begin{array}{l}\text { Callus induction } \\
(\% \text { Mean } \pm \mathrm{SE})\end{array}$ \\
\hline 0.0 & 0.0 & 0.0 \\
\hline 0.0 & 0.01 & 0.0 \\
\hline 0.0 & 0.1 & 0.0 \\
\hline 0.0 & 0.25 & 0.0 \\
\hline 0.0 & 0.5 & 0.0 \\
\hline 0.2 & 0.0 & $37.77 \pm 2.02$ \\
\hline 0.2 & 0.01 & $55.55 \pm 2.18$ \\
\hline 0.2 & 0.1 & $56.66 \pm 2.08$ \\
\hline 0.2 & 0.25 & $57.22 \pm 2.02$ \\
\hline 0.2 & 0.5 & $58.67 \pm 0.88$ \\
\hline 0.5 & 0.0 & $38.33 \pm 2.08$ \\
\hline 0.5 & 0.01 & $56.11 \pm 2.33 \mathrm{E}$ \\
\hline 0.5 & 0.1 & $58.88 \pm 1.20 \mathrm{E}$ \\
\hline 0.5 & 0.25 & $58.88 \pm 0.88 \mathrm{E}$ \\
\hline 0.5 & 0.5 & $74.66 \pm 3.84$ \\
\hline 1.0 & 0.0 & $52.22 \pm 2.40$ \\
\hline 1.0 & 0.01 & $89.44 \pm 2.60 \mathrm{E}$ \\
\hline 1.0 & 0.1 & $88.88 \pm 2.90 \mathrm{E}$ \\
\hline 1.0 & 0.25 & $90.55 \pm 2.33 \mathrm{E}$ \\
\hline 1.0 & 0.5 & $89.66 \pm 1.20$ \\
\hline 2.0 & 0.0 & $53.33 \pm 2.51$ \\
\hline 2.0 & 0.01 & $90.55 \pm 2.02 \mathrm{E}$ \\
\hline 2.0 & 0.1 & $91.66 \pm 2.08 \mathrm{E}$ \\
\hline 2.0 & 0.25 & $91.11 \pm 1.76$ \\
\hline 2.0 & 0.5 & $91.33 \pm 1.45$ \\
\hline 3.0 & 0.0 & $54.44 \pm 2.18$ \\
\hline 3.0 & 0.01 & $89.44 \pm 2.96$ \\
\hline 3.0 & 0.1 & $87.77 \pm 2.02$ \\
\hline 3.0 & 0.25 & $91.11 \pm 2.40$ \\
\hline 3.0 & 0.5 & $94.33 \pm 0.88$ \\
\hline 4.0 & 0.0 & $55.55 \pm 2.33$ \\
\hline 4.0 & 0.01 & $92.22 \pm 2.33$ \\
\hline 4.0 & 0.1 & $90.00 \pm 2.08$ \\
\hline 4.0 & 0.25 & $92.77 \pm 2.33$ \\
\hline 4.0 & 0.5 & $90.33 \pm 0.88$ \\
\hline 5.0 & 0.0 & $56.11 \pm 2.18$ \\
\hline 5.0 & 0.01 & $92.22 \pm 2.72$ \\
\hline 5.0 & 0.1 & $94.44 \pm 0.66$ \\
\hline 5.0 & 0.25 & $93.88 \pm 1.66$ \\
\hline 5.0 & 0.5 & $88.33 \pm 1.20$ \\
\hline
\end{tabular}

Mean \pm SE-Standard error of three repeated experiments; 60 Explants per treatment used; Medium: MS basal; Observations were recorded after 4 weeks; *E-Embryogenic callus with globular structures after 40 days of culture.
Hence hereafter all the experiments were evaluated using only MS medium. Amongst the media, MS medium showed best response in terms of callus induction and subsequent somatic embryogenesis. Generally different basal media such as MS, WPM, AE, B5, LM, MCM, SH, FN, $\mathrm{P}_{24}$ DCR, LP/QP, BN, MH1/CE, MeSo, BL, and BM have been used for the induction callus in tree species (Giri et al., 2004). In case of conifer Larix leptolepis, LP medium was found suitable for embryogenic tissue formation and proliferation when compared to LM and MS medium. Referring specifically, MS basal medium was used in many tree species for callus induction and somatic embryogenesis (Giri et al., 2004).

Table 2: Evaluation of different basal media on callus induction using MZE in T.chebula*

\begin{tabular}{|l|l|l|l|}
\hline Medium & $\begin{array}{l}\mathbf{2 , 4 - D} \\
\mathbf{m g} / \mathbf{l}\end{array}$ & $\begin{array}{l}\text { KN } \\
\mathbf{m g} / \mathbf{l}\end{array}$ & $\begin{array}{l}\text { Callus induction } \\
\text { (\% Mean } \pm \text { SE) }\end{array}$ \\
\hline MS & 1.0 & 0.0 & $52.22 \pm 2.40$ \\
& 1.0 & 0.01 & $89.44 \pm 2.60 \mathrm{E}$ \\
& 1.0 & 0.1 & $88.88 \pm 2.90 \mathrm{E}$ \\
& 1.0 & 0.25 & $90.55 \pm 2.33 \mathrm{E}$ \\
WPM & 1.0 & 0.5 & $89.66 \pm 1.20$ \\
& 1.0 & 0.0 & $42.22 \pm 2.42$ \\
& 1.0 & 0.01 & $61.11 \pm 1.33$ \\
& 1.0 & 0.1 & $67.78 \pm 1.11$ \\
& 1.0 & 0.25 & $74.66 \pm 3.84$ \\
& 1.0 & 0.5 & $74.66 \pm 3.84$ \\
& 1.0 & 0.0 & $43.88 \pm 0.55$ \\
& 1.0 & 0.01 & $58.80 \pm 1.47$ \\
& 1.0 & 0.1 & $62.77 \pm 2.42$ \\
& 1.0 & 0.25 & $77.22 \pm 1.46$ \\
& 1.0 & 0.5 & $76.11 \pm 3.64$ \\
\hline
\end{tabular}

MS: Murashige and Skoog; WPM: Woody plant medium; DKW: Driver and Kuniyuki; McGranahan; Mean \pm SE: Standard error of three repeated experiments; 60 Explants per treatment used; Observations were recorded after 4 weeks; *E-Embryogenic callus with globular structures after 40 days of culture.

MS medium supplemented with different concentrations of plants growth regulators either alone or in combinations such as 2, 4-D + $\mathrm{KN}, 2,4-\mathrm{D}+\mathrm{BA}, \mathrm{NAA}+\mathrm{KN}, \mathrm{NAA}+\mathrm{BA}, \mathrm{IBA}+\mathrm{KN}, \mathrm{IBA}+\mathrm{BA}$ were evaluated for callus induction. Callus induction and proliferation from explants was greater in the media with 2, 4-D in combination with KN compared to the media with 2, 4-D + BA, NAA+KN, $\mathrm{NAA}+\mathrm{BA}, \mathrm{IBA}+\mathrm{BA}, \mathrm{IBA}+\mathrm{KN}$. In the present study, amongst the plant growth regulators, 2, 4-D and kinetin promoted embryogenic callus induction, further proliferation and somatic embryogenesis (Table 3; Figure 2b, c). Cell division and differentiation is mainly regulated by plant growth regulators such as auxins and cytokinins. The influences of exogenously applied 2, 4-D are well documented on the induction of somatic embryogenesis. However, somatic embryo development was also reported in the absence of plant 
growth regulators as well as other plant growth regulators only cytokinins or ABA. Different plant growth regulators mainly auxins and cytokinins such as 2, 4-D, NAA, IAA, IBA, IPA, BA, KN, TDZ, 2iP, Zeatin were used for callus induction in tree species (Giri et al., 2004). A similar finding as in the present study embryogenic callus induction response was also observed with 2, 4-D and kinetin in Dalbergia sissoo, Terminalia arjuna. The present work with T.chebula revealed that combination of 2, 4-D and BA induced nodular calli and that did not become embryogenic after prolonged subculture in induction medium. However, in a recent report 2, 4$\mathrm{D}$ and BA combination promoted induction of embryogenic callus in Acacia sinuata. Thus, culture response may be attributed to endogenous levels of hormones in the explants of different genotypes used for callus induction and somatic embryogenesis (Giri et al., 2004).

Table 3: Effect of different plant growth regulators other than 2,4$\mathrm{D}$ and $\mathrm{KN}$ on callus induction from mature zygotic embryo explants in T. chebula*

\begin{tabular}{|c|c|c|}
\hline $\begin{array}{l}\text { Auxin } \\
\mathrm{mg} / \mathrm{l}\end{array}$ & $\begin{array}{l}\text { Cytokinin } \\
\mathrm{mg} / \mathrm{l}\end{array}$ & $\begin{array}{l}\text { Callus induction } \\
(\% \text { Mean } \pm \mathrm{SE})\end{array}$ \\
\hline $2,4-\mathrm{D}$ & $\mathrm{BA}$ & \\
\hline 1.0 & 0.01 & $70.55 \pm 3.38$ \\
\hline 1.0 & 0.1 & $78.33 \pm 1.45$ \\
\hline 1.0 & 0.25 & $78.89 \pm 1.11$ \\
\hline 1.0 & 0.5 & $82.77 \pm 0.55$ \\
\hline NAA & $\mathrm{KN}$ & \\
\hline 1.0 & 0.0 & $27.01 \pm 2.01$ \\
\hline 1.0 & 0.01 & $66.33 \pm 0.57$ \\
\hline 1.0 & 0.1 & $67.78 \pm 1.11$ \\
\hline 1.0 & 0.25 & $74.66 \pm 3.84$ \\
\hline 1.0 & 0.5 & $74.66 \pm 3.84$ \\
\hline NAA & BA & \\
\hline 1.0 & 0.01 & $63.88 \pm 1.76$ \\
\hline 1.0 & 0.1 & $69.44 \pm 2.22$ \\
\hline 1.0 & 0.25 & $71.11 \pm 1.11$ \\
\hline 1.0 & 0.5 & $73.88 \pm 2.42$ \\
\hline IB A & $\mathrm{KN}$ & \\
\hline 1.0 & 0.0 & $45.55 \pm 0.88$ \\
\hline 1.0 & 0.01 & $67.33 \pm 1.20$ \\
\hline 1.0 & 0.1 & $67.33 \pm 1.20$ \\
\hline 1.0 & 0.25 & $76.11 \pm 3.64$ \\
\hline 1.0 & 0.5 & $78.89 \pm 1.11$ \\
\hline IB A & B A & \\
\hline 1.0 & 0.01 & $56.11 \pm 0.88$ \\
\hline 1.0 & 0.1 & $62.33 \pm 1.20$ \\
\hline 1.0 & 0.25 & $79.66 \pm 2.90$ \\
\hline 1.0 & 0.5 & $78.33 \pm 1.45$ \\
\hline
\end{tabular}

Mean \pm SE-Standard error of three repeated experiments; 60 Explants per treatment used; MS basal medium was used for the study; Observations were recorded after 4 weeks; *E-Embryogenic callus with globular structures after 40 days of culture

\subsubsection{Effect of different plant growth regulators on callus induction from excised mature zygotic embryo explants in $T$. chebula}

MS medium supplemented with different plants growth regulators such as 2, 4-D + KN, 2, 4-D+BA, NAA+KN, NAA+BA, IBA+KN, IBA+BA were evaluated for callus induction (Table 3 ). The frequency of callus induction was less and non-embryogenic when auxins were used singly in the medium. NAA induced least frequency of callus induction $(27.01 \pm 2.01)$ compared to 2, 4-D (52.22 \pm $2.40)$ and IBA $(45.55 \pm 0.88)$. IBA $1 \mathrm{mg} / \mathrm{l}$ and BA $0.01 \mathrm{mg} / \mathrm{l}$ plant growth regulator combination produced less frequency $(56.11 \pm$ 0.88 ) of callus induction than 2, 4-D + KN, 2, 4-D+BA, NAA+KN, $\mathrm{NAA}+\mathrm{BA}, \mathrm{IBA}+\mathrm{KN}$. Plant growth regulator combinations 2, 4-D (1 $\mathrm{mg} / \mathrm{l})+\mathrm{KN}(0.01,0.1,0.25 \mathrm{mg} / \mathrm{l})$ produced embryogenic calli with a frequency of $89.44 \pm 2.60,88.88 \pm 2.90$ and $90.55 \pm 2.33$, respectively. In case of other PGR combinations, non-embryogenic calli was observed (Table 3 )

\subsection{Biochemical characterization of somatic embryogenesis in T. chebula}

\subsubsection{Study on embryo specific proteins at different stages of somatic embryo development}

A clear difference was observed between non-embryogenic and embryogenic callus in their physical texture and characteristics (Figure 3). Distinct visual difference existed in these callus cultures that the embryogenic callus was yellowish in colour in both dark and light regime where as the non-embryogenic callus cultures were white in colour in dark and intensely green in light conditions.

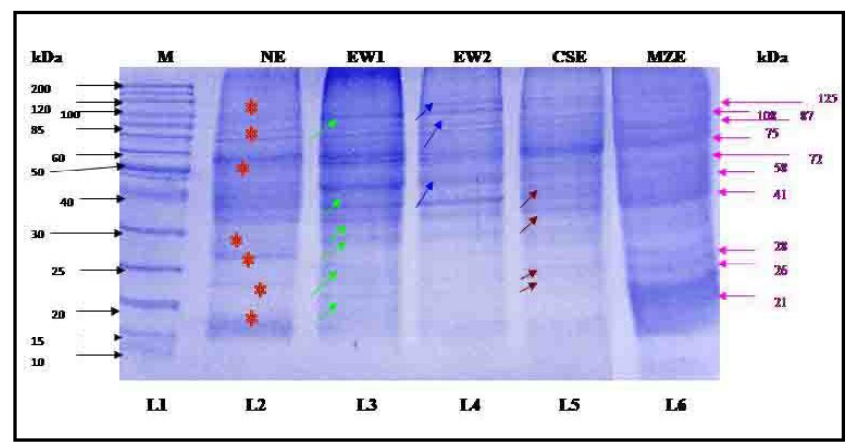

Figure 3: SDS-PAGE analysis of proteins at different developmental stages of somatic embryogenesis in T. chabula M-protein marker (L1); NE-non embryogenic callus (L2); EW1embryogenic callus after 1 week (L3); EW2-embryogenic callus after 2 week (L4); CSE-cotyledonary stage somatic embryos (L5); ZE-mature zygotic embryos (L6); L-lane, *Red colour star represents specific proteins bands present and are similar in L2, L3, L4, L5 and L6; $\rightarrow$-Green colour arrow represents somatic embryo specific protein bands in EW1; $\rightarrow-$ Blue colour arrow represents specific proteins bands in EW2; $\rightarrow$-Brown colour arrow repreents specific protein bands in CSE; $\rightarrow$ - Pink coour arrow represents specific protein bands in $\mathrm{ZE}$. 
Proteins isolated from non-embryogenic, embryogenic callus at different developmental stages were studied using 15\% SDS-PAGE. Protein bands of size $16 \mathrm{kD}, 22 \mathrm{kD}, 28 \mathrm{kD}, 32 \mathrm{kD}, 36 \mathrm{kD}, 40 \mathrm{kD}, 55$ $\mathrm{kD}, 68 \mathrm{kD}, 70 \mathrm{kD}, 74 \mathrm{kD}, 87 \mathrm{kD}$ were present in the SDS protein profile of non-embryogenic callus. Protein analysis revealed that somatic embryo specific proteins such as $21 \mathrm{kD}, 24 \mathrm{kD}, 30 \mathrm{kD}, 42$ $\mathrm{kD}, 52 \mathrm{kD}, 85 \mathrm{kD}$ were present in one week old embryogenic callus when compared to their absence in non-embryogenic tissue (Figure 3). The somatic embryo specific proteins were unique to the one week old embryogenic callus in addition to the presence of bands found in non-embryogenic callus. However, non-embryogenic callus showed characteristic protein bands (non-embryogenic specific proteins) of size $28 \mathrm{kD}, 74 \mathrm{kD}$ and these bands were absent in embryogenic callus.

Embryogenic callus after two weeks of in vitro culture revealed the presence of $53 \mathrm{kD}, 75 \mathrm{kD}, 110 \mathrm{kD}$ specific proteins. In this stage of embryogenic callus growth, developmental stages of somatic embryos from late globular to early cotyledonary stage occurred. Protein profile of isolated cotyledonary stage somatic embryos showed the presence of $24 \mathrm{kD}, 25 \mathrm{kD}, 33 \mathrm{kD}, 44 \mathrm{kD}$ proteins. Proteins bands such as $16 \mathrm{kD}, 22 \mathrm{kD}, 25 \mathrm{kD}, 29 \mathrm{kD}, 31 \mathrm{kD}, 68 \mathrm{kD}$, $80 \mathrm{kD}, 125 \mathrm{kD}$ were observed to be similar in non-embryogenic and embryogenic callus at different developmental stages i.e up to late cotyledonary stage. Amongst the above mentioned protein bands, the intensity of protein bands such as $16 \mathrm{kD}, 22 \mathrm{kD}, 26 \mathrm{kD}$ were more in non embryogenic callus and their expression was less in embrygenic callus across different developmental stages.

\subsubsection{Comparative study on the embryo specific proteins in somatic and zygotic embryos}

Comparative study of somatic embryo specific proteins with zygotic embryo proteins was evaluated. Protein bands such as $21 \mathrm{kD}, 26$ $\mathrm{kD}, 28 \mathrm{kD}, 41 \mathrm{kD}, 58 \mathrm{kD}, 72 \mathrm{kD} 75 \mathrm{kD}, 87 \mathrm{kD}, 108 \mathrm{kD}, 125 \mathrm{kD}$ were found in mature zygotic embryos. Extra prominent proteins bands such as $21 \mathrm{kD}, 75 \mathrm{kD}$ was found to be specific to mature zygotic embryos. Proteins bands such as $26 \mathrm{kD}, 28 \mathrm{kD}, 58 \mathrm{kD}, 108 \mathrm{kD}$, $125 \mathrm{kD}$ were similar in zygotic embryos, non-embryogenic callus and also in embryogenic callus with different developmental stages. Absence of proteins bands such as $16 \mathrm{kD}, 22 \mathrm{kD}, 36 \mathrm{kD}, 40 \mathrm{kD}, 55$ $\mathrm{kD}, 68 \mathrm{kD}, 70 \mathrm{kD}$, were observed in zygotic embryos, on the other hand, these bands were present in non-embryogenic callus, embryogenic callus at different developmental stages (Figure 3). Similarly, more intensity of protein bands $36 \mathrm{kD}, 56 \mathrm{kD}$ were observed in one week old embryogenic callus compared to their expression in non-embryogenic callus, two weeks old embryogenic callus and cotyledonary stage somatic embryos. A $55 \mathrm{kDa}$ prominent band was observed in cotyledonary stage somatic embryos compared to other stages of somatic embryos and non-embryogenic callus. Protein analysis revealed the expression of somatic embryo specific proteins in embryogenic callus compared to the non-embryogenic callus and other developmental stages necessary for the induction of somatic embryogenesis (Figure 3).

\subsubsection{Study on embryo specific proteins at different stages of somatic embryo development}

Somatic embryogenesis has been considered as an ideal experimental system for understanding the expression of totipotency. Molecular characterization of somatic embryogenesis can enhance our basic understanding of the developmental process underlying the formation of somatic and zygotic embryos. It will be useful in the development of stage specific molecular markers that can be used to optimize somatic embryogenesis protocols.

In the present study, non-embryogenic and embryogenic callus showed a clear difference in their morphology and physical texture. SDS-PAGE was used to analyze protein profile of non-embryogenic, embryogenic callus at different developmental stages. A detailed protein profile analysis was aimed at identifying specific proteins during different culture passages of embryogenic callus (viz., one and two weeks old). Proteins such as $21 \mathrm{kD}, 24 \mathrm{kD}, 30 \mathrm{kD}, 42 \mathrm{kD}$, $52 \mathrm{kD}, 85 \mathrm{kD}$ was found to be specific after one-week-old embryogenic callus containing globular structures when compared to their absence in non-embryogenic tissue. In addition to the bands found in non-embryogenic callus, these somatic embryos specific proteins were unique to one week old embryogenic callus. This clearly indicated that these proteins expressed specifically after one week old embryogenic callus for the induction of somatic embryogenesis with the simultaneous appearance of globular structures on the callus surface. A $30 \mathrm{kD}$ protein band observed in the present study was also found to be specific during 0 to 1 transition stage (fresh callus to preglobular masses) in Santalum album (Sankara et al., 1996).

Embryogenic callus after two weeks of in vitro culture revealed the presence and appearance of specific proteins such as $53 \mathrm{kD}, 75 \mathrm{kD}$, $110 \mathrm{kD}$. In this stage of embryogenic callus growth, developmental stages of somatic embryos from late globular to heart and early cotyledonary stage was found to occur. This observation showed that these proteins expressed may be related to the products of specific genes during the transition from globular to early cotyledonary developmental stage of somatic embryos after two weeks. Protein profile of cotyledonary stage somatic embryos showed the presence of proteins such as $24 \mathrm{kD}, 25 \mathrm{kD}, 33 \mathrm{kD}$, $44 \mathrm{kD}$. These proteins may be correlated to the products of cotyledonary stage developmental specific genes during the process of embryo maturation. The observations starting from the appearance of embryogenic specific proteins $21 \mathrm{kD}, 24 \mathrm{kD}, 30 \mathrm{kD}$, $42 \mathrm{kD}, 52 \mathrm{kD}, 85 \mathrm{kD}$ after one week in contrast to the nonembryogenic callus protein profile found to be present and extended up to cotyledonary stage of the embryogenic process. This finding indicated the possibility of differential expression and these set of genes or gene products may have some vital role for the maintenance of embryogenic potential of the tissue and subsequent regulation of different developmental stage of the somatic embryogenesis process.

It was evident from the profile that the degree of expression of majority of these proteins as possible gene products was on decline phase. Proteins bands such as $16 \mathrm{kD}, 22 \mathrm{kD}, 25 \mathrm{kD}, 29 \mathrm{kD}, 31 \mathrm{kD}$, $55 \mathrm{kD}, 68 \mathrm{kD}, 80 \mathrm{kD}, 125 \mathrm{kD}$ were observed to be similar in nonembryogenic and embryogenic callus at different developmental stages, i.e., up to late cotyledonary stage. The presence of these proteins in all stages of embryogenic callus and non-embryogenic callus may be related to the products of housekeeping genes. The constancy of the protein bands and their presence throughout the developmental stages may be attributed to their conserved nature.

The intensity of protein bands such as $16 \mathrm{kD}, 22 \mathrm{kD}, 26 \mathrm{kD}$ were more in non embryogenic callus and their expression was less in embrygenic callus at different developmental stages. Similarly, more 
intensity of protein bands $36 \mathrm{kD}, 56 \mathrm{kD}$ were observed in one week old embryogenic callus compared to their expression in nonembryogenic callus, two weeks old embryogenic callus and cotyledonary stage somatic embryos. A $55 \mathrm{kD}$ prominent band was observed in cotyledonary stage somatic embryos compared to other stages of somatic embryos and non-embryogenic callus. In a report, it has been found that over or under expression of certain genes induced somatic embryogenesis in Arabidopsis plants (Vogel, 2005). Protein analysis revealed the expression of somatic embryo specific proteins in embryogenic callus in comparison to the nonembryogenic callus and other developmental stages necessary for the induction of somatic embryogenesis.

\subsubsection{Comparative study on the embryo specific proteins in} somatic and zygotic embryos

Zygotic embryo formed as a consequence of egg cell fertilization, is clearly determined to follow the embryogenic cell fate. In other forms of plant embryogenesis such as apomixis, somatic embryogenesis, there is a transition of phase during which competent and embryogenic cell types are formed from normal somatic cells. This transition phase is very difficult to define, but an understanding of the underlying mechanisms can provide insight in to developmental strategy of plants.

Present study dealt with the comparison of somatic embryo specific proteins with zygotic embryo proteins was evaluated. Protein bands of size $21 \mathrm{kD}, 26 \mathrm{kD}, 28 \mathrm{kD}, 41 \mathrm{kD}, 58 \mathrm{kD}, 72 \mathrm{kD} 75 \mathrm{kD}, 87 \mathrm{kD}$, $108 \mathrm{kD}, 125 \mathrm{kD}$ were found in mature zygotic embryos. Extra prominent proteins with high intensity bands revealing higher degree of expression such as $21 \mathrm{kD}, 75 \mathrm{kD}$ were found to be specific to mature zygotic embryos. Proteins bands such as $26 \mathrm{kD}, 28 \mathrm{kD}, 58$ $\mathrm{kD}, 108 \mathrm{kD}, 125 \mathrm{kD}$ were observed both in zygotic embryos and non-embryogenic callus as well as in embryogenic callus with different developmental stages which included globular, heart, early cotyledonary and mature embryos. In non-embryogenic callus, embryogenic callus at different developmental stages, proteins bands such as $16 \mathrm{kD}, 22 \mathrm{kD}, 36 \mathrm{kD}, 40 \mathrm{kD}, 55 \mathrm{kD}, 68 \mathrm{kD}, 70 \mathrm{kD}$ were observed and these protein bands were absent in zygotic embryos. This clearly indicates that more number of proteins expressed in non-embryogenic callus and embryogenic callus at different developmental stages when compared to zygotic embryos. In the present study in Abies alba, higher number of proteins was also observed in somatic embryos than zygotic embryos (Kormutak et al., 2003). In earlier reports, it has been claimed that spatial and temporal gene expression programmes appear to be similar in somatic and zygotic embryos. Recently, it has been concluded from gene expression and molecular marker studies, although very limited, that greater differences than similarities between zygotic and somatic embryos (Krishnamurthy 1999). In a report, establishment of a new cellular state is not only controlled at the level of gene expression, but requires modification and or removal of unidentified polypeptides, as well as the proper folding of the newly synthesized proteins and protein complexes. This was demonstrated using twodimensional protein electrophoresis, which showed that dedifferentiation and subsequent somatic embryogenesis are associated with complex changes in the protein pattern (Feher et al., 2003).

Although, the morphological description of embryo development has been extensively recorded through microscopy, molecular and biochemical analyses of early embryogenesis has been hampered significantly by this physical inaccessibility. As a consequence, we know very little about the genes that are necessary for early embryogenesis in higher plants and even less about their regulation. There has been a report on the molecular mechanism for the somatic embryogenesis process using in vitro culture system of trees (Dong and Dunstan, 1999). In a recent report in Medicago truncatula, comparison of protein expression between highly embryogenic responsive 2HA line and wild-type Jemalong and found that more than 2000 proteins were expressed. Amongst the proteins, 54 proteins changed in expression during somatic embryogenesis. Mascot search engine and available EST database search revealed 16 differentially expressed proteins and more than $60 \%$ of the differentially expressed protein spots had very different patterns of gene expression between 2HA and Jemalong during the 8 weeks of culture (Imin et al., 2005). In a report, the pattern of expression of genes and the potential roles of their products in controlling somatic embryogenesis has been studied using cDNA-AFLP in Fraxinus angustifolia (Azamboni et al., 2005).

\subsection{Genetic transformation studies in T.chebula}

\subsubsection{Effect of different concentrations of antibiotic (cefotaxime) on the control of bacterial growth after co-cultivation in T.chebula}

In the present study, different concentrations of antibiotic cefotaxime ranging from 100 to $400 \mathrm{mg} / \mathrm{l}$ for the control of bacterial growth was evaluated. Amongst different concentrations of cefotaxime used, 350 and $400 \mathrm{mg} / \mathrm{l}$ showed $100 \%$ inhibition of growth of bacteria (Table 4).

Table 4: Effect of different concentrations of antibiotic (cefotaxime) on the control of bacterial growth in T.chebula

\begin{tabular}{|c|c|c|}
\hline $\begin{array}{c}\text { Cefotaxime } \\
\mathbf{m g} / \mathbf{l}\end{array}$ & $\begin{array}{l}\text { No of co-cultivated calli } \\
\text { transferred on to } \\
\text { antibiotic media }\end{array}$ & $\begin{array}{l}\text { No. of calli with out } \\
\text { infection }(\% \text { Mean } \pm \text { SE) }\end{array}$ \\
\hline 0.0 & 50 & 0.0 \\
100 & 60 & 0.0 \\
200 & 45 & $41.48 \pm 2.33$ \\
250 & 60 & $76.29 \pm 2.02$ \\
300 & 60 & $98.33 \pm 0.57$ \\
350 & 50 & 100.00 \\
400 & 45 & 100.00 \\
\hline
\end{tabular}

MS solid medium supplemented with 2, 4-D $1 \mathrm{mg} / \mathrm{l}$ and $\mathrm{KN} 0.01 \mathrm{mg} /$ 1 was used for the study; 2 weeks old calli was used for the study; Mean \pm SE: standard error of three repeated experiments; $72 \mathrm{~h}$ old callus explants after co-cultivation was used for the study; Observations were recorded after 4 weeks.

\subsubsection{Evaluation of different explants for genetic transfor- mation using LBA4404 containing pTOK233 in $T$. chebula}

Different explants such as cotyledon, freshly excised mature zygotic embryos, excised MZE after 5-6 and 18-20 days of in vitro culture in callus induction medium and embryogenic calli were co-cultivated with Agrobacterium tumefaciens strain to evaluate the degree of bacterial infection around the co-cultivated explants and to score culture response on genetic transformation (Table 5). Cotyledon, 
freshly excised embryos after $72 \mathrm{~h}$. of co-cultivation showed high degree of bacterial infection, blackening of explants and re-infection in subsequent culture to antibiotic media. High degree of bacterial infection, blackening of explants and vigorous re-infection of bacteria in subsequent culture was observed after $72 \mathrm{~h}$ of co-cultivation using explants initially cultured in callus induction medium for 5-6 days and 18-20 days. Amongst different explants used, embrygenic callus explants showed moderate infection of bacteria after $72 \mathrm{~h}$ of co-cultivation. The embryogenic callus explants were healthy and actively growing on subsequent culture passages when compared to other explants (Table 5).

Table 5: Evaluation of different explants for genetic transformation using A. tumefaciens strain pTOK233 in T. chebula.

\begin{tabular}{|l|c|c|l|}
\hline \multirow{2}{*}{ Explants } & \multicolumn{2}{|c|}{ Co-cultivation response after 72 h } & $\begin{array}{l}\text { Culture } \\
\text { response \# }\end{array}$ \\
\cline { 2 - 3 } & $\begin{array}{l}\text { No of explants used } \\
\text { for co-cultivation }\end{array}$ & $\begin{array}{l}\text { Degree of infection } \\
\text { around explants }\end{array}$ & \\
\hline $\mathrm{Cot}$ & 160 & +++ & $\mathrm{BE}$ \\
$\mathrm{Ee}^{\mathrm{F}}$ & 150 & +++ & $\mathrm{BE}, \mathrm{RI}$ \\
$\mathrm{Ee}(5-6$ days)* & 180 & +++ & $\mathrm{BE}, \mathrm{RI}$ \\
$\mathrm{Ee}(15-18$ days)** & 180 & +++ & BE, VRI \\
$\mathrm{Ec}$ & 200 & ++ & H, AGC \\
\hline
\end{tabular}

Cot: Cotyledon explants; $\mathrm{Ee}^{\mathrm{F}}$ : Freshly excised mature zygotic embryos Ee- Excised embryo (*-5-6, **-15-18 days of culture in callus induction medium); Ec- Embryogenic callus (2 weeks after subculture); All explants incubated in PIMII medium bacterial suspension for 10 min; Diameter of infection around explants - ++ : Moderate infection $(2-3 \mathrm{~mm})$; +++ : High infection ( $>4 \mathrm{~mm})$; ++++ : very high infection; \# : Observations were recorded after 4 weeks.

\subsubsection{Influence of co-cultivation technique and duration of treatment on bacterial growth using pTOK233 in T. chebula}

Different co-cultivation techniques such as calli dipped in PIM II bacterial suspension for different time, i.e., 5, 10, 15 min durations, PIM II bacterial suspension poured over embryogenic calli freshly placed on co-cultivation medium was evaluated for degree of bacterial infection after $72 \mathrm{~h}$.

Table 6: Influence of co-cultivation techniques and duration of treatment on bacterial growth using pTOK233 in T.chebula

\begin{tabular}{|l|c|c|c|}
\hline $\begin{array}{l}\text { Nature of } \\
\text { co-cultivation }\end{array}$ & $\begin{array}{c}\text { Duration of } \\
\text { tratment } \\
\text { (min) }\end{array}$ & $\begin{array}{c}\text { No of calli } \\
\text { co-cultivated } \\
\text { callus after 72 } \mathbf{~ h}\end{array}$ & $\begin{array}{c}\text { Degree of bacterial } \\
\text { infection around }\end{array}$ \\
\hline $\begin{array}{l}\text { Calli dipped in } \\
\text { PIM II bacterial } \\
\text { suspension }\end{array}$ & 5 & 200 & + \\
& 10 & 200 & ++ \\
$\begin{array}{l}\text { PIM II bacterial } \\
\text { suspension } \\
\text { poured over } \\
\text { calli }(20 \mu \mathrm{l})\end{array}$ & - & 220 & +++ \\
\hline
\end{tabular}

MS solid medium PH-5.2 supplemented with 2, 4-D $1 \mathrm{mg} / \mathrm{l}$ and $\mathrm{KN}$ $0.01 \mathrm{mg} / \mathrm{l}$ was used for the study; 2 weeks old calli was used for the study; Diameter of bacterial infection around explants - + : Less infection $(<1 \mathrm{~mm})$; ++ : Moderate infection $(2-3 \mathrm{~mm})$; +++ : High infection $(>4 \mathrm{~mm})$.
Co-cultivation treatment was given for different time durations ranged from 5-15 min (Table 6). Amongst these two methods, embryogenic calli dipped in PIM II bacterial suspension for $10 \mathrm{~min}$ duration showed moderate bacterial infection, no re-infection was observed after subsequent culture passages and found suitable for genetic transformation (Table 6). In case of embryogenic calli dipped in PIM II bacterial suspension for $15 \mathrm{~min}$ and PIM II bacterial suspension poured over embryogenic calli showed high bacterial infection around calli and re-infection in subsequent culture passage.

\subsubsection{Effect of co-cultivation period and degree of bacterial infection on embryogenic calli explants using pTOK233 in T. chebula}

In the present work, the effect of co-cultivation period on degree of bacterial infection was investigated. In one day co-cultivation experiment, very less bacterial infection was observed around the explants. Moderate bacterial infection around embryogenic calli was observed when the calli co-cultivated for 2 days (Table 7). Profuse overgrowth of bacteria was observed when the explants co-cultivated for more than two days and it resulted in blackening of the explants.

Table 7: Effect of co-cultivation period and degree of bacterial infection on calli explants using pTOK233 in T.chebula

\begin{tabular}{|c|c|c|}
\hline $\begin{array}{c}\text { Co-cultivation } \\
\text { period (days) }\end{array}$ & $\begin{array}{c}\text { No of calli } \\
\text { co-cultivated }\end{array}$ & $\begin{array}{c}\text { Degree of bacterial } \\
\text { infection around calli }\end{array}$ \\
\hline 1 & 160 & + \\
2 & 200 & ++ \\
3 & 160 & +++ \\
4 & 170 & $++++\mathrm{BE}$ \\
\hline
\end{tabular}

MS solid medium PH-5.2 supplemented with 2, 4-D $1 \mathrm{mg} / \mathrm{l}$ and $\mathrm{KN}$ $0.01 \mathrm{mg} / \mathrm{l}$ was used for the study; 2 weeks old calli was used for the study; calli dipped in PIM II medium bacterial suspension for $10 \mathrm{~min}$; Observations were recorded after 4 weeks; Bacterial infection around explant- +: Less infection $(<1 \mathrm{~mm}) ;++$ : Moderate infection $(2-3$ $\mathrm{mm}) ;+++$ : High infection $(>4 \mathrm{~mm}) ;++++$ : very high infection; $\mathrm{BE}$ - Blackening of explants.

3.4.1.4 Study on the effect of hygromycin on non transformed embryogenic calli growth and evaluation of optimum concentration of hygromycin for selection of transformants in T.chebula

The present work was undertaken to determine lethal concentration of selection agent hygromycin on embryogenic calli. Embryogenic calli were placed on MS medium containing different concentrations of hygromycin ranging from 5 to $80 \mathrm{mg} / \mathrm{l}$ (Table 8). A frequency of 14.810 .57 and $27.05 \pm 0.88$ embryogenic calli turned brown when cultured on medium containing $5.0 \mathrm{mg} / \mathrm{l}, 10.0 \mathrm{mg} / \mathrm{l}$ hygromycin, respectively. About $96.51 \pm 0.88$ calli turned brown when embryogenic calli transferred to MS medium containing $40 \mathrm{mg} / \mathrm{l}$ hygromycin. These calli did not survive after 3 weeks, where, as $100 \%$ lethality was observed after 3 weeks when $60 \mathrm{mg} / \mathrm{l}$ and 80 $\mathrm{mg} / \mathrm{l} \mathrm{hygromycin} \mathrm{was} \mathrm{incorporated} \mathrm{in} \mathrm{the} \mathrm{medium} \mathrm{(Figure} 4 \mathrm{~b}$ ). Based on the results, $60 \mathrm{mg} / \mathrm{l}$ hygromycin was used as selection medium for the selection of transformed calli in subsequent genetic transformation experiments. 
3.4.1.5 Effect of different concentrations of acetosyringone used for the pretreatment of embryogenic calli on frequency of transformants resistant to hygromycin following co-cultivation with pTOK233 in T. chebula

Different concentrations of acetosyringone pretreatment were evaluated on the frequency of transformants with respect to hygromycin resistance. Calli pretreated for 20 min with $50 \mathrm{mM}$, $100 \mathrm{mM}, 200 \mathrm{mM}$ acetosyringone and others without pretreatment as control were co-cultivated for scoring hygromycin resistant calli. The less frequency of hygromycin resistant calli $(3.12 \pm 1.15)$ was observed with $50 \mathrm{mM}$ acetosyringone pretreated calli (Table 8). The highest frequency of hygromycin resistant calli $(5.20 \pm 1.45)$ was observed with $100 \mathrm{mM}$ acetosyringone pretreated calli when compared to other pretreatments (Table 9). A frequency of $4.58 \pm$ 1.76 hygromycin resistant calli was obtained with $200 \mathrm{mM}$ acetosyringone pretreated calli and $0.90 \pm 0.88$ hygromycin resistant calli was obtained from calli with out acetosyringone pretreatment subsequent to co-cultivation (Figure 4c). Induction of somatic embryogenesis was obtained from hygromycin resistant calli (Figure $4 d)$. These embryogenic cultures were further used for the study of GUS gene expression.

Table 8: Study on the effect of hygromycin on non-transformed calli growth and evaluation of optimum concentration of hygromycin for selection of transformants in T.chebula

\begin{tabular}{|c|c|l|}
\hline $\begin{array}{c}\text { Concentration of } \\
\text { hygromycin }(\mathbf{m g} / \mathbf{l})\end{array}$ & $\begin{array}{c}\text { No of calli } \\
\text { inoculated }\end{array}$ & $\begin{array}{l}\text { Calli killed } \\
\text { (\% Mean } \pm \text { SE) }\end{array}$ \\
\hline 0.0 & 28 & 0.0 \\
5.0 & 28 & $14.81 \pm 0.57$ \\
10.0 & 30 & $27.05 \pm 0.88$ \\
20.0 & 28 & $58.13 \pm 0.33$ \\
40.0 & 28 & $96.51 \pm 0.88$ \\
60.0 & 28 & 100.00 \\
80.0 & 28 & 100.00 \\
\hline
\end{tabular}

MS solid medium supplemented with 2, 4-D $1 \mathrm{mg} / 1, \mathrm{KN} 0.01 \mathrm{mg} / \mathrm{l}$ was used for the study; 28-30 calli explants inoculated in each experiment; Mean \pm SE: standard error of three repeated experiments; Observations were recorded after 4 weeks.

Table 9: Effect of different concentrations of acetosyringone used for the pretreatment of embryogenic calli on frequency of transformants resistant to hygromycin following cocultivation with pTOK233 in T. chebula

\begin{tabular}{|c|c|}
\hline $\begin{array}{c}* \text { AS concentration } \\
\boldsymbol{\mu M}\end{array}$ & $\begin{array}{c}\text { No of calli showed resistance to } \\
\text { hygromycin }(\% \text { Mean } \pm \text { SE) }\end{array}$ \\
\hline 0.0 & $0.90 \pm 0.88$ \\
50 & $3.12 \pm 1.15$ \\
100 & $5.20 \pm 1.45$ \\
200 & $4.58 \pm 1.76$ \\
\hline
\end{tabular}

*AS: Calli was pretreated in MS liquid medium supplemented with AS (50 to $200 \mu \mathrm{M}) 2$, 4-D $1 \mathrm{mg} / \mathrm{l}$ and $\mathrm{KN} 0.01 \mathrm{mg} / \mathrm{l}$ for $20 \mathrm{~min}$; 2 weeks old calli was used for the study; calli dipped in PIM II medium bacterial suspension for $10 \mathrm{~min}$; Mean \pm SE: standard error of three repeated experiments; A minimum of 480 calli pieces was used for each treatment Observations were recorded after 5 weeks

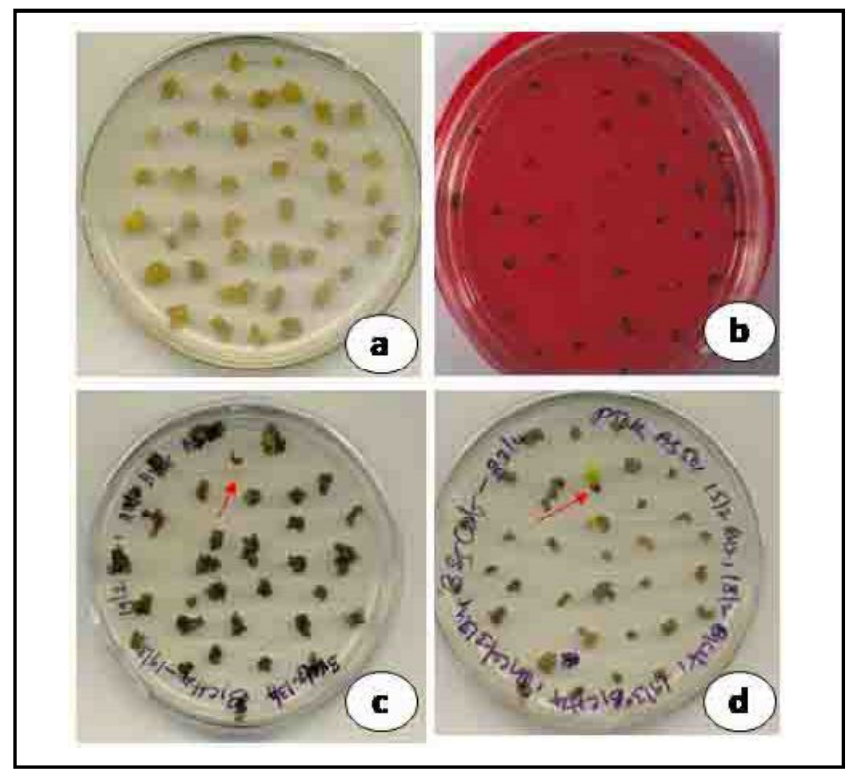

Figure 4: Evaluation of lethal dose of hygromycin concentration in control and transformed callus using Agrobacterium tumefaciens containing pTOK233 in T.chebula a. Untransformed control callus without hygromycin selection; b. untransformed control callus in hygromycin selection $(60 \mathrm{mg} / \mathrm{l})$ medium showing complete death of the tissues; c. transformed callus in hygromycin selection medium showing sections of resistant calli (red arrow); $\mathbf{d}$. transformed callus in hygromycin selection medium showing induction of somatic embryogenesis (red arrow).

3.4.1.6 Study of callus pretreatment using different concentrations of acetosyringone on transient expression of GUS gene in calli transformed with pTOK233 in T. chebula

Different concentrations of acetosyringone was used for callus pretreatment and evaluated for the frequency of transformants showing transient GUS expression. Calli pretreated for $20 \mathrm{~min}$ with $50 \mathrm{mM}, 100 \mathrm{mM}, 200 \mathrm{mM}$ acetosyringone and other without pretreatment as control were co-cultivated for recording GUS expression (Table 10). The less frequency of $3.77 \pm 1.73$ GUS expression was observed with $50 \mathrm{mM}$ acetosyringone pretreated calli. The highest frequency of GUS expression $(4.44 \pm 1.76)$ was observed with $100 \mathrm{mM}$ acetosyringone pretreated calli when compared to other acetosyringone pretreated calli and $0.74 \pm 0.40$ frequency GUS expression with untreated calli. A frequency of 4.01 \pm 2.30 GUS expression was obtained with $200 \mathrm{mM}$ acetosyringone pretreated calli (Table 10).

Table 10: Study of callus pretreatment using different concentrations of acetosyringone on transient expression of GUS gene in calli transformed with pTOK233 in T.chebula

\begin{tabular}{|c|c|}
\hline $\begin{array}{c}\text { *AS concentration } \boldsymbol{\mu M} \text { (calli } \\
\text { dipped for } 20 \text { min) }\end{array}$ & $\begin{array}{c}\text { No of calli showed gus } \\
\text { expression }(\% \text { Mean } \pm \text { SE) }\end{array}$ \\
\hline 0.0 & $0.74 \pm 0.40$ \\
50 & $3.77 \pm 1.73$ \\
100 & $4.44 \pm 1.76$ \\
200 & $4.01 \pm 2.30$ \\
\hline
\end{tabular}


*AS: Calli was pretreated in MS liquid medium supplemented with AS $(100 \mu \mathrm{M})$ 2, 4-D $1 \mathrm{mg} / \mathrm{l}$ and $\mathrm{KN} 0.01 \mathrm{mg} / \mathrm{l}$ for $20 \mathrm{~min} ; 2$ weeks old calli was used for the study; calli dipped in bacterial suspension for $10 \mathrm{~min}$; Mean \pm SE: standard error of three repeated experiments; A minimum of 45-49 calli pieces was used for each treatment; Observations were recorded after 4 weeks.

Transfer of GUS gene and its expression was reconfirmed by staining hygromycin resistant callus with x-gluc solution. Clear blue staining of transformed callus was obtained compared to its absence in nontransformed callus (Figure 5a). Further, hygromycin resistant embryogenic callus containing somatic embryos showed GUS staining compared to its absence in somatic embryos of control callus (Figure $5 b$ ).

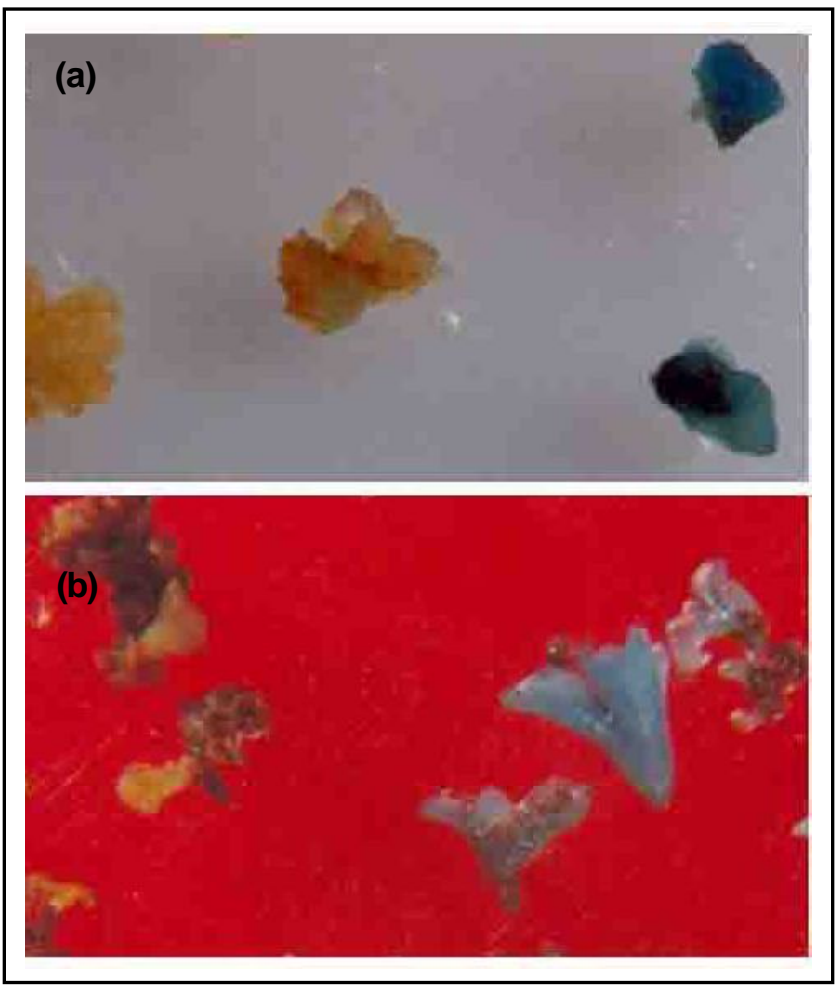

Figure 5: Genetic transformation using Agrobacterium tumefaciens containing pTOK233 in T.chebula a. Untransformed calli without GUS expression (left); transformed calli showing GUS expression (right); b. untransformed somatic embryos without GUS expression (left); transformed somatic embryos showing GUS expression (right).

Advances in the genetic transformation of forest trees have made it possible to transfer chimeric genes of academic, agronomic and economic importance to the genome of recipient species. Agrobacterium mediated genetic transformation method was mostly used for the transformation of majority of the tree species (Giri et al., 2004). Genetic transformation study in T.chebula involving selectable marker and reporter gene was initiated with no prior background literature on Agrobacterium mediated transformation in this plant. Therefore, it was necessary to deal with all preliminary standardization experiments such as response to antibiotic cefotaxime for control of bacterial growth as well as estimation of optimal concentration of selection agent e.g hygromycin subsequent to transformation.
In the present study, different concentrations of antibiotic cefotaxime was evaluated for the control of bacterial growth. Cefotaxime concentration $350 \mathrm{mg} / \mathrm{l}$ was found that best response in controlling of bacterial growth. As the concentration of the antibiotic increased from 100 to $400 \mathrm{mg} / \mathrm{l}$, the degree of inhibition of bacterial growth was evident and $350 \mathrm{mg} / \mathrm{l}$ was found optimal. Cefotaxime at the concentration of $250 \mathrm{mg} / \mathrm{l}$ was used in shoot regeneration medium to control bacteria in Vaccinium corymbosum (Song and Sink, 2004). Antibiotics such as cefotaxime, carbenecillin, timentin, augmentin, triacillin, etc., were used to control bacterial growth in transformation experiments in tree species (ref: Table II). Explants such as cotyledon, freshly excised mature zygotic embryos, excised MZE after 5-6 and 18-20 days of culture in callus induction medium and embryogenic calli were co-cultivated with Agrobacterium tumefaciens strain to evaluate the degree of bacterial infection around the co-cultivated explants and subsequent culture response. Amongst the explants, embryogenic callus was found to be suitable for co-cultivation with Agrobacterium tumefaciens. Cotyledon and freshly excised mature zygotic embryos after co-cultivation showed high degree of bacterial infection, blackening of explants and reinfection of bacteria in subsequent culture. High degree of bacterial infection, blackening of explants and vigorous re-infection of bacteria in subsequent culture was observed with 5-6 days and 18-20 days old excised embryos. The embryogenic callus explants were healthy and actively growing on subsequent culture passages when compared to other explants.

In earlier studies, a similar embryogenic callus explant was used for transformation in Hevea brasiliensis, Chamaecyparis obtusa (Montoro et al., 2003; Taniguchi et al., 2005). Mature zygotic embryo of T.chebula unique in its features such as absence of endosperm. The cotyledons of zygotic embryo were folded in the form of whorls. Bacteria present in the folding of cotyledon obtained from MZE and entire MZE explants possibly not exposed to antibiotic present in the medium. In the present study, cotyledon, mature zygotic embryo explants were not found suitable for transformation, it may be due to low meristematic activity, rate of cell division of these explants. Embryogenic callus was found suitable for transformation because of the presence of more meristematic activity and rate of cell division. Differentiated tissues such as cotyledon and MZE released more phenolics when compared to undifferentiated callus which possibly may affect the transformation. Different co-cultivation techniques such as calli dipped in PIM II bacterial suspension for different time durations, PIM II bacterial suspension poured over embryogenic calli freshly placed on co-cultivation medium was evaluated on degree of bacterial infection. In our study, $20 \mathrm{~min}$ acetosyringone pretreated embryogenic calli dipped in PIM II bacterial suspension for $10 \mathrm{~min}$ was found suitable for transformation. A similar 10 min incubation of calli in bacterial suspension was reported in Hevea brasiliensis (Montoro et al., 2003). However, example of plants other than tree, i.e., in indica rice transformation, $30 \mathrm{~min}$ acetosyringone pretreated embryogenic calli showed best transformation response (Ramesh et al., 2004).

The effect of period of co-cultivation using embryogenic calli explants on degree of bacterial infection was investigated. A two days co-cultivation period was found suitable for transformation in T.chebula. In earlier studies, a similar co-cultivation period of 2 
days was used for transformation in Quercus suber, Chamaecyparis obtusa (Alvarez et al., 2004; Taniguchi et al., 2005). After cocultivation thorough washing of calli was found essential to prevent subsequent bacterial growth on media containing cefotaxime. When the co-cultivated calli were not washed, the bacteria grew intensely on the medium and led to the browning of callus and subsequent death of the embryogenic calli. Therefore, a thorough washing of calli was a critical step in the transformation protocol in T.chebula. In earlier studies, a similar protocol was adapted in Chamaecyparis obtusa to reduce excessive bacterial contamination (Taniguchi et al., 2005). The observation of the present study clearly indicated that prolonging the co-cultivation period beyond two days was detrimental and resulted in a profuse over growth of the bacteria, which eventually suppressed the growth of the embryogenic callus.

The lethal concentration of selection agent hygromycin on embryogenic callus was evaluated. Embryogenic callus was placed on callus induction medium containing different concentrations of hygromycin. Based on the results obtained from the experiments, the concentration of hygromycin $(60 \mathrm{mg} / \mathrm{l})$ which showed $100 \%$ lethality was used as selection medium for the selection of transformed calli. In earlier studies, a similar hygromycin selection agent at a concentration $0.5 \mathrm{mg} / \mathrm{l}$ in case of Coffea canephora and $50 \mathrm{mg} / \mathrm{l}$ in case of Picea mariana was used for the selection of transformed tissues (Hatanaka et al., 1999; Tian et al., 2000). Selectable marker genes such as gus, nptII, hpt, bar, gfp were used for transformation in tree species (Giri et al., 2004; Häggman et al., 2013; Häggman et al., 2016; Andrade et al., 2017).

Transformation frequency was evaluated with regard to transient GUS expression using calli with different concentrations of acetosyringone pretreatment. Amongst the acetosyringone pretreated calli, $100 \mu \mathrm{M}$ acetosyringone pretreated calli showed best transformation response. However, $100 \mathrm{mM}$ acetosyringone preated calli was reported in indica rice transformation (Ramesh $e t$ al., 2004). Calli was incubated in PIM II bacterial suspension containing $100 \mu \mathrm{M}$ acetosyringone for $10 \mathrm{~min}$ was found suitable for transformation in T.chebula. In earlier report a similar $100 \mu \mathrm{M}$ acetosyringone in bacterial suspension was improved transformation frequency in Vaccinium corymbosum (Song and Sink, 2004). However, bacterial suspension containing different concentrations of acetosyringone 10-25 mM in case of Hevea brasiliensis and $50 \mu \mathrm{M}$ in case of Chamaecyparis obtusa was used for explants cocultivation (Jayashree et al., 2003; Taniguchi et al., 2005; Andrade et al., 2017). In the present study, the genetic transformation of $T$. chebula has been possible to develop a preliminary procedure for transfer of selectable marker gene and reporter gene such as hpt and GUS, respectively.

\section{Conclusion}

SDS-PAGE protein profile analysis revealed that some of the specific proteins such as $21 \mathrm{kD}, 24 \mathrm{kD}, 30 \mathrm{kD}, 42 \mathrm{kD}, 52 \mathrm{kD}, 85$ $\mathrm{kD}$ were associated with the induction of somatic embryogenesis and these proteins were absent in non-embryogenic callus. Hygromycin $60 \mathrm{mg} / \mathrm{l}$ as lethal concentration was used for selection of transformed calli in T.chebula. The highest transformation (4.44 \pm 1.76 GUS expression, $5.20 \pm 1.45$ hygromycin resistant calli), frequency was obtained with $100 \mu \mathrm{M}$ acetosyringone pretreated embryogenic calli. The observations obtained on the genetic transformation were studied for the first time in T.chebula using somatic embryogenesis system.

\section{Acknowledgments}

The authors would like to thank the APNL Biotechnology Programme of The Netherlands Ministry for Development and Co-operation for the financial support. C. Anjaneyulu would like to thank CSIR, New Delhi for the award of a Senior Research Fellowship during the doctoral study.

\section{Conflict of interest}

We declare that we have no conflict of interest.

\section{References}

Afshari, A.R.; Sadeghnia, H.R. and Mollazadeh H. (2016). A review on potential mechanisms of Terminalia chebula in Alzheimer's disease. Adv. Pharmacol. Sci., 2016-Article ID 8964849, pp:1-14.

Alvarez, R.; Alonso, P.; Cortizo, M.; Celestino, C.; Hernoodez, I.; Torbio, M. and Ordas, R.J. (2004). Genetic transformation of selected mature cork oak (Quercus Suner L) trees. Plant Cell Rep., 23:218-223.

Andrade G.; Shah, R.; Johansson, S.; Pinto, G. and Egertsdotter, U. (2017). Somatic embryogenesis as a tool for forest tree improvement: a case-study in Eucalyptus globules. BMC Proc., 5:128.

Anjaneyulu, C. and Giri, C.C. (2008). Factors influencing somatic embryo maturation, high frequency germination and plantlet formation in Terminalia chebula Retz. Plant Biotechnol. Rep., 2:153-161.

Anjaneyulu, C. and Giri, C.C. (2011). Direct somatic embryogenesis from mature zygotic embryo and conversion to plants in medicinal tree Terminalia chebula Retz.Tree Forestry Sci. Biotechnol., $5: 32-37$

Azamboni, A.; Dondini, D. and Tonon, G. (2005). cDNA-AFLP study of gene expression during somatic embryogenesis in Fraxinus aungustifolia Vhal. The J. of Horticult. Biotech., 80:240-244.

Bagnoli, F.; Capuana, M. and Racchi, M.L. (2005). Developmental changes of catalase and superoxide dismutase isoenzymes in zygotic and somatic embryos of horse chestnut. Aust. J. Plant Physiol., 25: 909-913.

Bonjar, G.H.S. (2004). Evaluation of antibacterial properties of Iranian medicinal plants against Micrococcus luteus, Serratia marcescens, Klebsiella pneumoniae and Bordetella bronchoseptica. Asian J. Plant Sci., 3:82-86.

Bradford, M.M. (1976). A rapid and sensitive method for the quantitation of microgram quantities of protein utilizing the principle of protein dye binding. Anal. Biochem., 72:248-254

Chadha, Y.R. (1989). The Wealth of India Publication and Information Directorate, CSIR, New Delhi, pp:171-177.

Dangi, B.; Kachhwaha, S. and Kothari, S.L. (2012). Regeneration and Agrobacterium-mediated genetic transformation of Terminalia bellerica Roxb.: A multipurpose tree species. In Vitro Cell. Dev.Biol.-Plant., 48:304-312.

Dong, J.Z. and Dunstan D.I. (1999). Cloning and characterization of six embryogenesis associated cDNAs from somatic embryos of Picea glauca and their comparative expression during zygote embryogenesis. Plant Mol. Biol. 39:859-864.

Driver, J.A. and Kuniyuki, A.H. (1984). In vitro propagation of Paradox walnut rootstocks. HortSci., 19:507.

Feher, A.; Pasternak, T.P. and Dudits, D. (2003). Transition of somatic plant cells to an embryogenic state. Plant Cell Tiss. Org. Cult., 74:201228 . 
Fernando, S.C.; Goodger, J.Q.D., Gutierrez,S.S.; Johnson, A.A.T. and Woodrow I.E. (2016). Plant regeneration through indirect organogenesis and genetic transformation of Eucalyptus polybractea R.T. Baker. Ind. Crop. Prod., 86: 73-78.

Georgeta F.; Courtelb, P.; Garciab, E.M.; Hidalgoc, Martin Alpizarb, E.; Breitlera J.C.; Bertranda, B. and Etienneaa, H. (2017). Somatic embryogenesisderived coffee plantlets can be efficiently propagated by horticultural rooted mini-cuttings: A boost for somatic embryogenesis. Scien. Horticult., 216: 177-185.

Giri, C.C.; Shyamkumar, B. and Anjaneyulu, C. (2004). Progress in tissue culture, genetic transformation and applications of biotechnology to trees: an overview. Trees, 18:115-135.

Guan, Y.; Li, S.G.; Fan, X.F. and Su, Z.H. (2016). Application of somatic embryogenesis in woody plants. Front. Plant Sci.,7 Article 938:112.

Häggman, H.; Raybould, A.; Borem, A.; Fox, T.; Handley, L.; Hertzberg, M.; Lu, M.Z; Macdonald, P.; Oguchi, T.; Pasquali, G.; Pearson, L.; Peter, G.; Quemada, H.; Séguin, A.; Tattersall, K.; Ulian, E.; Walter, C. and McLean M. (2013). Genetically engineered trees for plantation forests: key considerations for environmental risk assessment. Plant Biotechnol. J., 11:785-798.

Häggman, H.; Sutela, S. and Fladung, M. (2016). Genetic engineering contribution to forest tree breeding efforts. In: Biosafety of forest transgenic trees. Springer, 1:11-29.

Hatanaka, T.; Choi, Y.E.; Kusano, T. and Sano, H. (1999). Transgenic plants of coffee (Coffea canephora) from embryogenic callus via Agrobacterium tumefaciens-mediated transformation. Plant Cell Rep., 19:106-110.

Imin, N.; Nizamidin, M.; Daniher, D.; Nolan, K.E.; Rose, R.J. and Rolfe, B.G. (2005). Proteomic analysis of somatic embryogenesis in Madicago truncatula. Explant cultures grown under 6-Benzylaminopurine and 1-Naphthaleneacetic acid treatments. Plant physol., 137: $1250-1260$

Jaya, P.G.; Rajeshkumar, N.V.; Rajesh, L.T.; Anuj, S.; James, W.; Steven, R.M.; Anoop, K.S. and Radha, K.M. (2004). Protective effect of a polyherbal preparation, Brahma rasayana against tumor growth and lung metastasis in rat prostate model system. J. Exp. Therapeutics Oncology, 4:203-212.

Jayashree, R.; Rekha, K.; Ventakachalam, P.; Urats, U.S.L.; Dandekar, A.M.; Jayasree, P.K.; Kala, R.G.; Priya, P.; Sushma K umari, S.; Sobha, S.; Ashokan, M.P.; Sethuraj, M.R. and Thulasidharan, A. (2003). Genetic Transformation and regeneration of rubber tree (Hevea Brasiliensis Muell. Arg) transgenic plants with a constitute version of an antioxidative stress superoxide dismutage gene. Plant Cell Rep., 22: 201-209.

Jefferson, R.A.; Kavanagh, T.A. and Bevan, M.W. (1987). GUS fusions: $\beta$ glucuronidase as a sensitive and versatile gene fusion marker in higher plants. EMBO J., 6:3901-3907.

Jeyaseelan, M. and Rao, M.V. (2005). Biochemical studies of embryogenic and non-embryogenic callus of Cardiospermum halicacabum L. Indian J. Exp. Biol. 43:555-560.

Jing, D.; Zhang J.; Xia Y.; Kong L.; Y, F.O.; Z, S.; Zhang, H. and Wang, J. (2017) Proteomic analysis of stress-related proteins and metabolic pathways in Picea asperata somatic embryos during partial desiccation. Plant Biotechnol. J. 15:27-38.

Jokar,A.; Masoomi, F.; Sadeghpour, O.; Nassiri-Toosi, M. and Hamedi, S. (2017). Potential therapeutic applications for Terminalia chebula in Iranian traditional medicine. J. Tradit. Chin. Med., 36(2): 250254

Josefina, P.M. and Patricio, A.J. (2005). Transgenic trees for a new era. In vitro Cell. Dev. Biol. Plant 41: 91-101.

Khare, C.P. (2004). In: Encyclopedia of Indian medicinal plants. SpringerVerlag Berlin Heiddberg, Germany pp: 451-453.
Kim M.S.; Lee D.Y.; Sung S.H. and Jeon W.K. (2018). Anti-cholinesterase activities of hydrolysable tannins and polyhydroxytriterpenoid derivatives from Terminalia chebula Retz. Fruit. Rec. Nat. Prod. 12:284-289.

Kong, L.; Holtz, C.T.; Nairn, C.J.; Houke, H.; Powell, W.A. Baier, K. and Merkle S.A. (2014). Application of airlift bioreactors to accelerate genetic transformation in American chestnut. Plant Cell. Tiss. Organ Cult., 117:39-50.

Kormutak, A.; Salaj, T.; Matusova, R. and Vookova, B. (2003). Biochemistry of zygotic and somatic embryogenesis in Silver Fir (Abies alba Mill). Acta Biol. Cracoviensia Series Botanica, 45:59-62.

Krishnamurthy, K.V. (1999). On embryos and embryoids. Curr. Sci., 76: 647-659.

Kumar, R.; Arora, R.; Agarwal, A. and Gupta Y.K. (2018). Protective effect of Terminalia chebula against seizures, seizure-induced cognitive impairment and oxidative stress in experimental models of seizures in rats. J. Ethnopharmacol., 215:124-13

Laemmli, U.K. (1970). Cleavage of structural proteins during the assembly of the head of bacteriophase $\mathrm{T}_{4}$. Nature, 227:680-685.

Lee, D.Y.; Kim, H.W.; Yang, H. and Sung, S.H. (2017). Hydrolyzable tannins from the fruits of Terminalia chebula Retz and their a-glucosidase inhibitory activities. Phytochem., 137:109-116.

Lee, S.I.; Hyun, P.M.; Kim, S.H.; Lee, S.K.; Kim, B.S.; Maeng, P.J. and Lim, J.S. (2005). Suppression of the onset and progression of collagen induced arthritis by chebulagic acid screened from a natural product library. Arthr. Rheum., 52(1):345-353.

Li, X.; Han, J.D.; Fang, Y.H.; Bai S.N. and Rao, G.Y. (2017). Expression analyses of embryogenesis-associated genes during somatic embryogenesis of Adiantum capillus-veneris L. In vitro: New insights into the evolution of reproductive organs in land plants. Front. plant Sci., 8 Article 938:1-12.

Lloyd, G. and Mc Cown, B. (1980). Commercially feasible micropropagation of mountain laurel, Kalmia latifolia, by use of shoot culture. Comb. Proc. Int. Plant Prop. Soc., 30:421-427.

Mc Granahan, G.H.; Driver, J.A. and Tulecke, W. (1987). Tissue culture of Juglans. In: Bonga JM, Durzan DH (eds) Cell and tissue culture in forestry, Vol 3. Martinus Nijhoff, Boston, MA, pp:261-271.

Montoro, P.; Rattana, W.; Pujade-Renaud, V.; Michaux-Ferriere, N.; Monkolsook, Y.; Kanthapura, R and Adunsadthapong, S. (2003). Production of Hevea brasiliensis transgenic embryogenic callus lines by Agrobacterium tumefaciens: Roles of calcium. Plant Cell Rep., 21:1095-1102.

Murashige, T. and Skoog, F. (1962). A revised medium for rapid growth and bioassays with tobacco tissue culture. Physiol. Plant, 15:473497.

Ohri, D. (1996). Genome size and polyploidy variation in the tropical hardwood genus Terminalia (Combretaceae). Plant Syst. Evol.; 200(3-4):225-232.

Puigderrajols, P.; Jofre, A.; Mir, G.; Pla, M.; Verdaguer, H.G. and Molinas, M. (2002). Developmentally and stress-induced small heat shock proteins in cork oak somatic embryos. J. Exp. Bot., 53:14451452 .

Ramesh, S.; Nagadhara, D.; Reddy, VD. and Rao, K.V. (2004). Production of transgenic indica rice resistant to yellow stem borer and sapsucking insects, using super binary vectors of Agrobacterium tumefaciens. Plant Sci., 166: 1077-1085.

Ramesh, S.; Nagadhara, D.; Reddy, VD. and Rao, K.V. (2004). Production of transgenic indica rice resistant to yellow stem borer and sapsucking insects, using super binary vectors of Agrobacterium tumefaciens. Plant Sci., 166: 1077-1085.

Saha, S and Verma, R.J. (2016). Antioxidant activity of polyphenolic extract of Terminalia chebula Retz fruits. J. Taibah. Univ. Sci., 10:805-812. 
Sandip, B. (2003). Medicinal plants with anti-HIV potential. Journal of Medicinal and Aromatic Plant Sci., 25:427-440.

Sankara, R.K.; Chrungoo, N.K. and Sinha, A. (1996). Characterization of somatic embryogenesis in sandalwood (Santalum album L.). In vitro cell and Dev. Biol. Plant, 32:123-128.

Saxena, S.; Lakshminarayan N.; Gudli, S. and Kumar, M. (2017). Antibacteria efficacy of Terminalia Chebula, Terminalia Bellirica, Embilica Officinalis and Triphala on salivary Streptococcus mutans count A linear randomized cross over trial. J. Clin. Diagno. Res., 11(2): ZC47-ZC51.

Shyamkumar, B. and Giri, C.C. (2011). High frequency shoot proliferation, rooting, acclimatization and field establishment of Terminalia chebula: A tree of pharmaceutical importance. Tree Forestry Sci. Biotechnol., 5:38-44.

Shyamkumar, B.; Anjaneyulu, C. and Giri, C.C. (2007). Genetic transformation of Terminalia chebula Ritz. and detection of tannin in transformed tissue. Curr. Sci., 92:361-367.

Shyamkumar, B.; Anjaneyulu, C. and Giri, C.C. (2003). Multiple Shoot Induction from cotyledonary node explants of Terminalia chebula. 47(4):585-588

Song, G.Q. and Sink, K.C. (2004). Agrobacterium tumefaciens-mediated transformation of blueberry (Vaccinium corymbosum L.). Plant Cell Rep., 23:475-484.

Suchalatha, S. and Shyamala, D.C.S. (2004). Protective effect of Terminalia chebula against experimental myocardial injury induced by isoproterenol. Ind. J. Exp. Biol., 42:174-178.

Suguna, L.; Singh, S.; Sivakumar, P. and Sampath, P. (2002). Influence of Terminalia chebula on dermal wound healing in rats. Phytotherapy Res., 16:227-231.

Taniguchi, T.; Kurita, M.; Ohmiya, Y. and Kondo, T. (2005). Agrobacterium tumefaciens mediated transformation of embryogenic tissue and transgenic plant regeneration in Chamaecyparis obtusa Sieb. et Zucc. Plant Cell Rep., 23:796-802.
Taniguchi, T.; Kurita, M.; Ohmiya, Y. and Kondom T. (2005). Agrobacterium tumefaciens mediated transformation of embryogenic tissue and transgenic plant regeneration in Chamaecyparis obtusa Sieb. Plant Cell Rep., 23:796-802.

Tian, L.N.; Charest, P.J.; Seguin, A. and Rutledge, R.G. (2000). Hygromycin resistance is an effective selectable marker for biolistic transformation of black spruce (Picea mariana). Plant Cell Rep., 19:358-362.

Veni, T.; Pushpanathan, T. and Mohanraj J. (2017). Larvicidal and ovicidal activity of Terminalia chebula Retz. (Family: Combretaceae) medicinal plant extracts against Anopheles stephensi, Aedes aegypti and Culex quinquefasciatus. J. Parasit. Dis., 41(3):693702 .

Verma, Y.S.; Kanwar, K. and Bhardwaj, S.V. (2013). Regeneration and transformation studies in Terminalia chebula Retz. JSIR, 72:563571 .

Warrier, P. K.; Nambiar, V.P.K. and Ramankutty, C. (1997). In: Indian medicinal plants a compendium of 500 species: Arya Vaidyasala, Orient Longman Ltd. Hyderabad, pp 263-274.

Xia, Y.; Zhang, J.; Jing, D.; Kong, L.; Zhang, S. and Wang, J. (2017). Plant regeneration of Picea asperata Mast. by somatic embryogenesis. Trees, 31:299-312.

Xu, H, X,; Wan, M.; Loh, B.N.; Kon, O.L.; Chow, P.W. and Sim, K.Y. (1996). Screening of traditional medicines for their inhibitory activity against HIV-1 protease. Phytotherapy Res., 10:207-210.

Yi, Z.C.; Wang, Z.; Hai-Xia, L.I.; Liu, M.J.; Wu, R.C. and Wang, H.X. (2004). Effects of chebulinic acid on differentiation of human leukemia K562 cells. Acta. Pharmacol. Sin., 25:231-238.

Zuo, L.; Yang, R.; Zhen, Z.; Liu, J.; Huang, L. and Yang, M. (2018). A 5 -year field study showed no apparent effect of the Bt transgenic 741 poplar on the arthropod community and soil bacterial diversity. Scientific Rep. 8:1956-1-13. 